\title{
ABORDAGEM HISTÓRICA E ARTÍSTICA DO USO DAS CORES AZUL E ROSA COMO PEDAGOGIAS DE GÊNERO E SEXUALIDADE
}

João Paulo Baliscei

Resumo

Este artigo de cunho bibliográfico e analítico tem o objetivo de investigar, a partir de aspectos históricos e artísticos, como as cores azul e rosa têm desempenhado pedagogias de gênero e sexualidade em sociedades ocidentais. Adotaram-se os Estudos Culturais e Estudos das Relações de Gênero, aproximando-os de produções artísticas em que o azul e o rosa foram associados a gêneros específicos. Demonstram-se indícios de que, antes do século XX, no ocidente, fora comum identificar meninos de rosa e meninas de azul. Posterior ao século XX, porém, as identificações cromáticas passaram a ser inversas, isto é, o azul foi associado às masculinidades e o rosa, às feminilidades. Por fim, apontam-se referências da Arte Contemporânea a partir das quais o uso convencional do azul e do rosa é questionado e subvertido. Palavras-chave: gênero; cor; imagem; educação; infância.

\section{HISTORICAL AND ARTISTIC APPROACH TO THE USE OF BLUE AND PINK COLORS AS PEDAGOGIES OF GENDER AND \\ SEXUALITY}

Abstract

This bibliographical and analytical paper aims to investigate, from historical and artistic aspects, how the blue and pink colors have played gender and sexuality pedagogies in western societies. Cultural Studies and Gender Studies were used, related to artistic productions where blue and pink were associated with specific genders. Demonstrates that, before the 20th century, in the west, it was common to identify boys with pink and girls with blue. After the 20th century, however, the chromatic identifications became inverse, that is, blue was associated with masculinities and pink, with femininities. Finally, references to Contemporary Art are pointed out, from which the conventional use of blue and pink is questioned and subverted.

Keywords: gender; color; image; education; childhood.

\section{ENFOQUE HISTÓRICO Y ARTÍSTICO DEL USO DE LOS COLORES AZUL Y ROSA COMO PEDAGOGÍAS DE GÉNERO Y SEXUALIDAD}

Resumen

Este artículo bibliográfico y analítico tiene el objetivo de investigar, desde aspectos históricos y artísticos, cómo los colores azul y rosa han realizado pedagogías de género y sexualidad en las sociedades occidentales. Se utilizaron los Estudios Culturales y Estudios de Género, relacionados a producciones artísticas donde el azul y el rosa se asociaron con géneros específicos. Demuestra de que, antes del siglo XX en el oeste, fuera común identificar a los niños de rosa y a las niñas de azul. Después del siglo XX, sin embargo, las identificaciones cromáticas se volvieron inversas, es decir, el azul se asoció con las masculinidades y el rosa, con las feminidades. Finalmente, se señalan referencias al Arte Contemporáneo, de las cuales se cuestiona y se subvierte el uso convencional del azul y del rosa.

Palabras clave: género; color; imagen; educación; infancia. 


\section{A SUPOSTA "NOVA ERA" DO AZUL-MENINO E ROSA-MENINA}

\section{Atenção. Atenção. É uma nova era no Brasil: menino veste azul e menina veste rosa. \\ (Damares Regina Alves, 2019)1}

No segundo dia de janeiro de 2019, um vídeo protagonizado por Damares Regina Alves (1964-) repercutiu nas redes sociais, na mídia televisiva e em grupos de conversas familiares e promoveu discussões sobre gênero. Nesse vídeo, a ministra da Mulher, da Família e dos Direitos Humanos, comemora sua posse e, sendo filmada, anunciou o início de "uma nova era no Brasil", como destacamos na epígrafe deste artigo. Eufórica e apoiada por seguidores entusiasmados/as, Damares logo evidencia o motivo da suposta nova era, anunciando que, nela, meninos vestiriam azul e meninas, rosa. Se por um lado o pronunciamento da ministra foi recebido com jocosidade e desprezo por algumas esferas sociais que reconhecem e criticam seu posicionamento político, por outro, encontrara apoio em grupos que buscam resgatar e conservar uma concepção mais tradicional dos papéis desempenhados por meninos e meninas. Considerando o poder e influência política que Damares exerce e as distintas reações que ocasionou é possível afirmar que a normativa "menino veste azul e menina veste rosa" tem atuado como pedagogia de gênero e sexualidade e inscreve os corpos e comportamentos infantis.

O conceito pedagogia de gênero e sexualidade, que inclusive compõe o título deste artigo, compreende que tanto o gênero quanto a sexualidade não são identidades naturais e isentas de atravessamentos culturais; são, ao contrário, construções sociais, políticas e, sobretudo, pedagógicas. Como afirma Guacira Lopes Louro (2008, p. 18)², a construção dos gêneros e das sexualidades "[...] dá-se através de inúmeras aprendizagens e práticas, insinua-se nas mais distintas situações, é apreendida de modo explícito ou dissimulado por um conjunto inesgotável de instâncias sociais e culturais". Assim, o conceito chama atenção para a existência de um conjunto de atributos que tentam conter, ajustar, disciplinar e punir os sujeitos para que se adequem àquilo que a sociedade avalia como "normal".

Em outro estudo, Louro (2016) argumenta que, socialmente, a ideia de "normalidade" está associada ao cumprimento da sequência sexo-gênero-sexualidade, que é cobrada (e esperada) do sujeito antes mesmo de seu nascimento. Segundo a lógica de raciocínio que subsidia a valorização dessa sequência, o sexo seria visto como algo "dado" e insubordinado à cultura e que determinaria um gênero específico. O gênero, por sua vez, induziria, dentro dessa perspectiva, a uma exclusiva sexualidade. Logo, uma criança nascida com órgãos sexuais masculinos, por exemplo, seria indiscutivelmente um menino e desempenharia desejos por alguém do gênero oposto, portanto, heterossexual. Contudo, a sequência sexo-gênero-sexualidade, assim como o status de normalidade que ela detém, são, por vezes subvertidos e, por isso, precisam ser reiterados constantemente e de modos ora explícitos, ora sutis. Para a autora, "[...] um trabalho pedagógico contínuo, repetitivo e interminável é posto em ação para inscrever nos corpos o gênero e a sexualidade "legítimos" (LOURO, 2016, p. 17).

Nos últimos anos, a produção científica associada aos Estudos Culturais e aos Estudos das Relações de Gênero tem se dedicado a investigar as maneiras pelas quais os artefatos da cultura

1 Essa manifestação feita pela ministra fora registrada em vídeos, tais como aquele disponível no link https://www.youtube.com/watch?v=q6X3-nXjmv4. Acesso em 22 maio 2020.

${ }^{2}$ Neste artigo, para dar visibilidade ao gênero dos e das autoras mencionados/as, decidi-me, politicamente, por transcrever seus nomes completos na primeira vez que os/as cito. Tal estratégia tem sido adotada por estudiosas e estudiosos de gênero, como Megg Rayara Gomes de Oliveira (2017) e bell hooks (2019), para desestabilizar algumas das características sexistas da linguagem. 
visual vêm atuando como pedagogias de gênero e de sexualidade, e produzindo significados sobre corpos e comportamentos infantis de modo a valorizar aquilo que socialmente tem sido considerado como "normal" e "comum". Nesse ponto concordamos com Louro (2016, p. 89) quando afirma: “[...] corpos considerados 'normais' e 'comuns' são, também, produzidos através de uma série de artefatos, acessórios, gestos e atitudes que uma sociedade arbitrariamente estabeleceu como adequados e legítimos". Portanto, até mesmo o gênero e a sexualidade daqueles/as considerados "normais" trata-se de construções feitas na e pela cultura. Porém, como destaca Jaqueline Gomes de Jesus (2012) as influências culturais que concorrem para a construção social dos gêneros não são totalmente visíveis e explícitas. Com isso, conforme a autora, as diferenças entre homens e mulheres são, muitas vezes tomadas como "naturais", ou lidas unicamente a partir de critérios biológicos, mais especificamente, dos órgãos genitais - o que desconsidera corpos e identidades que não correspondem à heterossexualidade e cisgenereidade, por exemplo.

Quando argumentou que "menino veste azul e menina veste rosa", a ministra Damares deixou transparecer não só a tentativa e desejo por usar das cores para disciplinar os corpos infantis conforme uma "normalidade" específica, assim como revelou que desconhece - ou pelo menos que desconsidera em seus pronunciamentos - que as associações feitas entre azul e masculinidade e rosa e feminilidade também são construções de um ideal, portanto, ideologia (no sentido de serem um conjunto de convicções defendidas por um grupo a partir de suas práticas culturais). Esse contexto e os desdobramentos que ele ocasionou nos levou a seguinte problema de pesquisa: Historicamente, como as cores têm sido utilizadas como pedagogias de gênero e sexualidade? Para formular respostas a essa pergunta, desenvolvemos este artigo de cunho bibliográfico e analítico cujo objetivo é investigar, a partir de aspectos históricos e artísticos, como as cores azul e rosa têm desempenhados pedagogias de gênero e sexualidade em sociedades ocidentais.

No que tange à estrutura, organizamos esta reflexão em três momentos para além desta introdução. No primeiro deles, respaldamo-nos na produção artístico-visual e em simbologias cromáticas e aspectos históricos. Explicamos e exemplificamos que, até o início do século XX, em sociedades ocidentais, fora comum o uso generificado das cores diferentemente do que se estabelece como norma na contemporaneidade: o rosa caracterizava meninos e o azul, meninas. Depois, em um segundo momento, apresentamos expressões que demonstram as transformações culturais, econômicas, religiosas e de gênero dos séculos XX e XXI que, paulatinamente, contribuíram para que o rosa fosse associado às mulheres e o azul, aos homens. Por fim, no terceiro momento, compartilhamos de referências vindas da Arte Contemporânea que utilizam as cores azul e rosa para questionar e subverter os significados que tradicionalmente são atribuídos aos corpos e às personalidades de meninos/homens e meninas/mulheres.

Nesse ponto, é preciso informar que com esta proposta, não pretendemos atribuir a um/a artista, movimento estético, personalidade, instituição ou acontecimento histórico, isoladamente, a associação que hoje é feita entre as cores e os gêneros. Mais do que localizar marcos históricos que justifiquem a associação feita entre rosa e feminilidade e azul e masculinidade, buscamos demonstrar, ao longo do texto, que o uso generificado das cores é uma construção social, portanto, passível de questionamento. Concordamos com a concepção de Peter Burke (2017) de que as imagens - fotografias, pinturas, esculturas e cinema - não reproduzem a realidade de maneira neutra, e que até mesmos aquelas que recorrem a técnicas e estilos realistas adulteram, simulam e subvertem o evento representado. As imagens, de fato, podem ser tomadas como evidências que documentam o passado, contudo, não são capazes de refleti-lo em sua complexidade. Esse processo de distorção da realidade, por si só, é, para Burke (2017, p. 50), evidência de fenômenos importantes a serem estudados, "[...] tais como mentalidades, ideologias e identidades. A imagem material ou literal é uma boa evidência da 'imagem' mental ou metafórica do eu e dos outros”. Logo, as pinturas, 
fotografias, publicidades, design, moda, desenhos infantis e outras expressões culturais as quais recorremos ao longo deste texto, podem ser considerados não só documentos que revelam o uso das cores como pedagogias de gênero e sexualidade, mas também, testemunhas das intenções que atravessam as representações de sujeitos generificados.

\section{Antes do século XX: azul-Maria e rosa-Cristo}

Nos séculos XVII e XVIII, o branco foi a cor predominantemente utilizada para caracterizar e vestir os bebês em seus primeiros anos de vida, fossem meninos ou meninas. William Ferreira (2018) explica o uso do branco na caracterização das crianças recém nascidas a partir de um fator simbólico. Para ele, a cor branca ressaltava os aspectos de inocência, pureza e proteção que já começavam a ser conferidos aos sujeitos infantis à época. Ana Paula Passarelli (2018), por sua vez, atribui o emprego da cor branca a questões prático-funcionais. Segundo a autora, para ser lavada, a roupa branca exige menos cuidados do que as roupas coloridas, as quais, em contato com a água, tendem a perdem cor. Esse argumento também guarda relações com o fato de, em algumas culturas do século XVII e XVIII, meninas e meninos usarem vestidos - o que facilitaria a troca de fraldas e a higienização.

As crianças representadas pelos artistas holandeses do século XVII, Govert Flinck (16151660) e Dirck Santvoort (1610-1680), assim como pela artista francesa Berthe Morisot (1841-1895) e pela estadunidense Mary Cassatt (1844-1926), do século XIX, são exemplos da adoção do branco para caracterizar os corpos infantis. Na Figura 1, tanto as pinturas expressivas do Barroco holandês, quanto as do Impressionismo, não nos dão pistas quanto ao gênero das crianças representadas.

Figura 1: Govert Flinck, Menina ao lado de cadeira alta, 1640; Dirck Santvoort, Menino de branco, 1641; Berthe Morisot, O Berço, 1872; e Mary Cassat, Um beijo para a bebê Anne, 1897
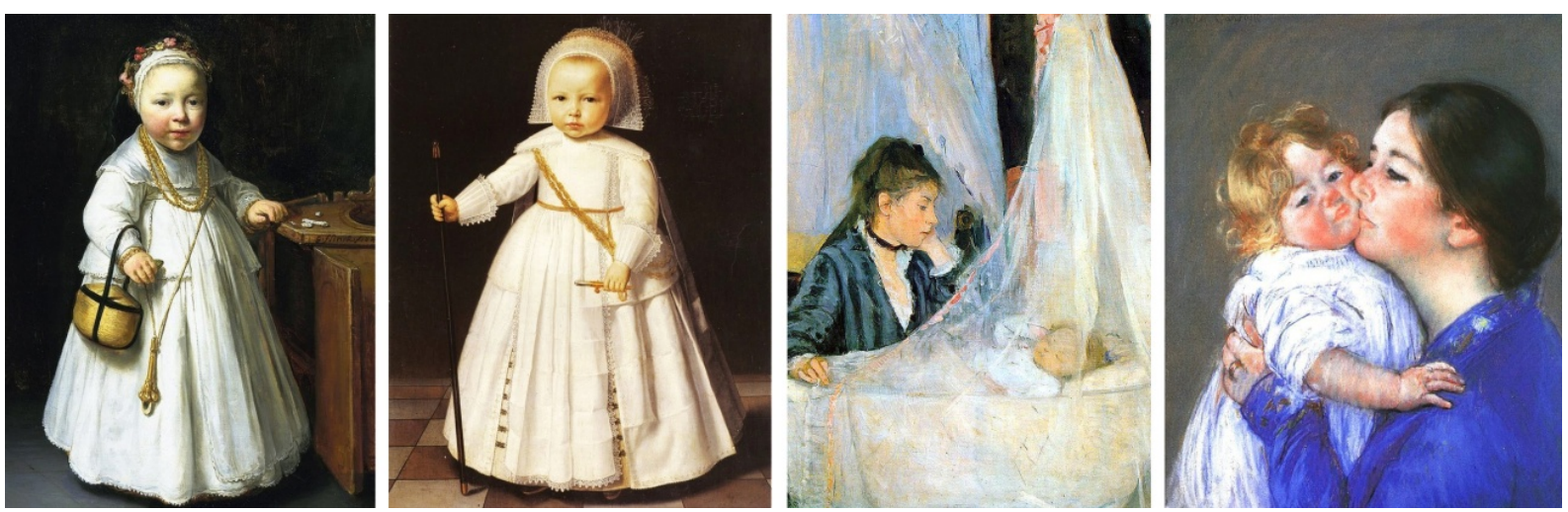

Fonte: Disponível em https://www.google.com.br. Acesso em 6 mar. 2019.

As roupas, adereços e cores empregadas na caracterização dos sujeitos infantis dessas pinturas de períodos e contextos artístico-geográficos tão diferentes nos sugerem que, no século XVII, na Holanda, e no século XIX, na França e Estados Unidos, meninos e meninas não eram normatizados/as pelo azul e rosa. Passarelli (2018) explica ainda que entre famílias menos abastadas, a adoção do branco para vestir as crianças estava relacionada à necessidade de fazer um bom aproveitamento das peças, que eram compartilhadas e repassadas entre irmãos/ãs e primos/as sem levar em consideração seu gênero.

Entretanto, expressões artísticas de diferentes períodos e contextos documentam que, no âmbito da representação, ainda no século XVII, os meninos e as meninas foram sim diferenciados 
pelo emprego das cores. Nesse caso, porém, a associação era justamente inversa àquela que se apresenta hoje como norma, ou seja, os meninos usavam rosa e as meninas, azul. Ainda conforme Passarelli (2018), como os homens adultos líderes políticos faziam uso de roupas e acessórios vermelhos - em referência à força, à determinação e ao sangue - era recomendado aos meninos vestirem-se com tonalidades rosa, ou seja, um vermelho desbotado. A autora relaciona a simbologia de poder atribuída ao vermelho à raridade de suas matérias primas e às dificuldades envolvidas na produção dessa pigmentação. Daí um dos porquês de o vermelho ser usado ao longo da história para marcar o gênero e a autoridade de homens adultos em posição de liderança, como pode ser percebido nas pinturas que reunimos na Figura 2. Os detalhes das composições barrocas do pintor flamengo Peter Rubens (1577-1640) não só caracterizam as capas que distinguem as figuras masculinas das femininas, como também sublinham a liderança e a valentia dos homens retratados.

Figura 2: Peter Paul Rubens, Cardeal Infante D. Fernando da Áustria na Batalha de Nördlinger, 1634-5; A luta de São Jorge com o dragão, 1606-8; e Andrômeda libertada por Perseu, 1639-41
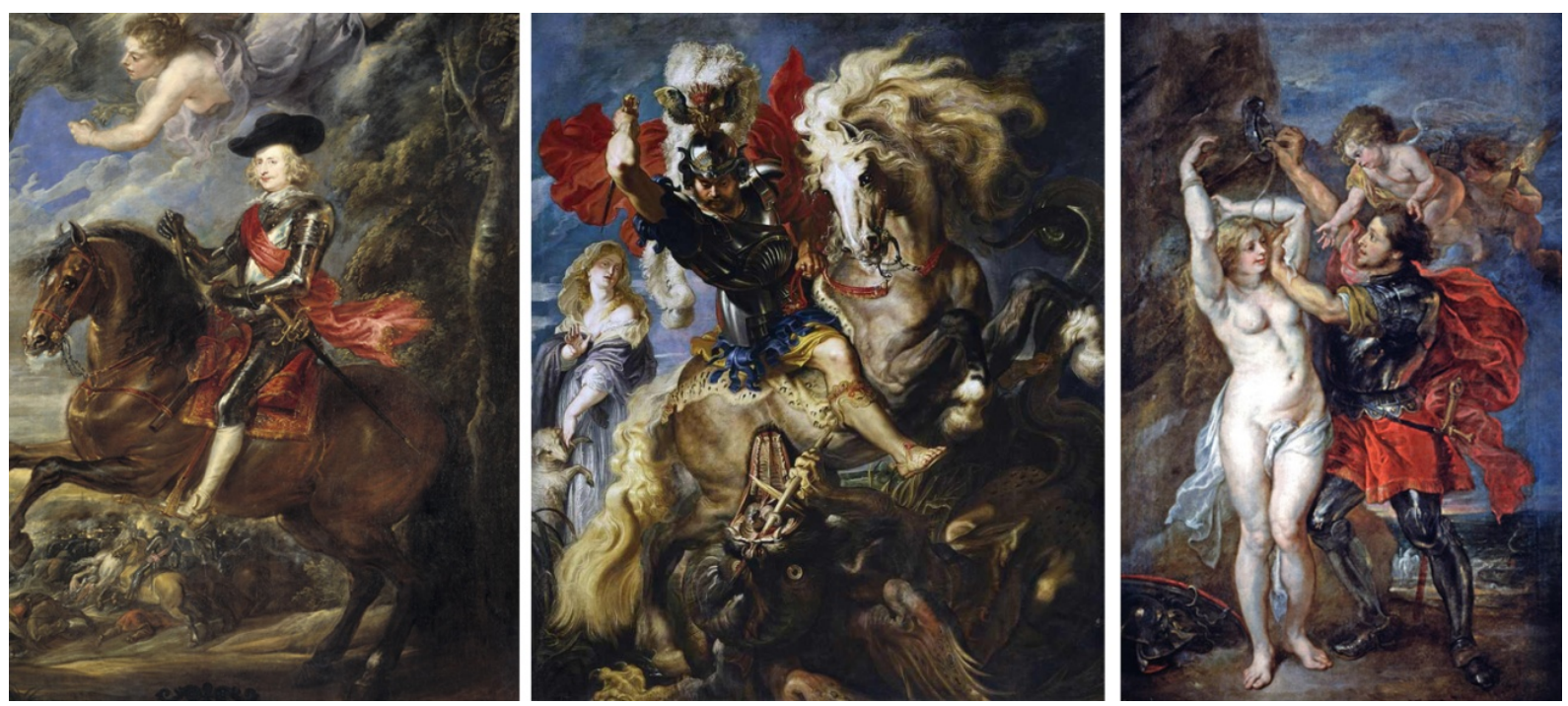

Fonte: Disponível em https://www.google.com.br. Acesso em 6 mar. 2019.

Por consequência dessa simbologia associada ao vermelho, o rosa - um vermelho mais claro - foi utilizado para caracterizar sujeitos infantis masculinos, os quais, futuramente, ocupariam o espaço político de seus pais. Destacamos essa relação entre rosa e as infâncias masculinas na Figura 3. Nela, reunimos quatro recortes de retratos do príncipe espanhol Baltasar Carlos (1629-1646), feitos pelo pintor espanhol Diego Velázquez (1599-1660) entre 1631 e 1646, sob a estética do Barroco. Além de documentarem que a construção da masculinidade do príncipe fora iniciada ainda durante seus primeiros anos de vida e que ele fora ensinado a desempenhar habilidades relacionadas à liderança e aos preparos para a guerra - as quatro imagens têm em comum o uso da cor rosa. 
Figura 3: Diego Velázquez. O príncipe Baltasar Carlos com anão, 1631; Príncipe Baltasar Carlos, 1632; O príncipe Baltasar Carlos a cavalo, 1635; e O príncipe Baltasar Carlos com 11 anos, 1641-46
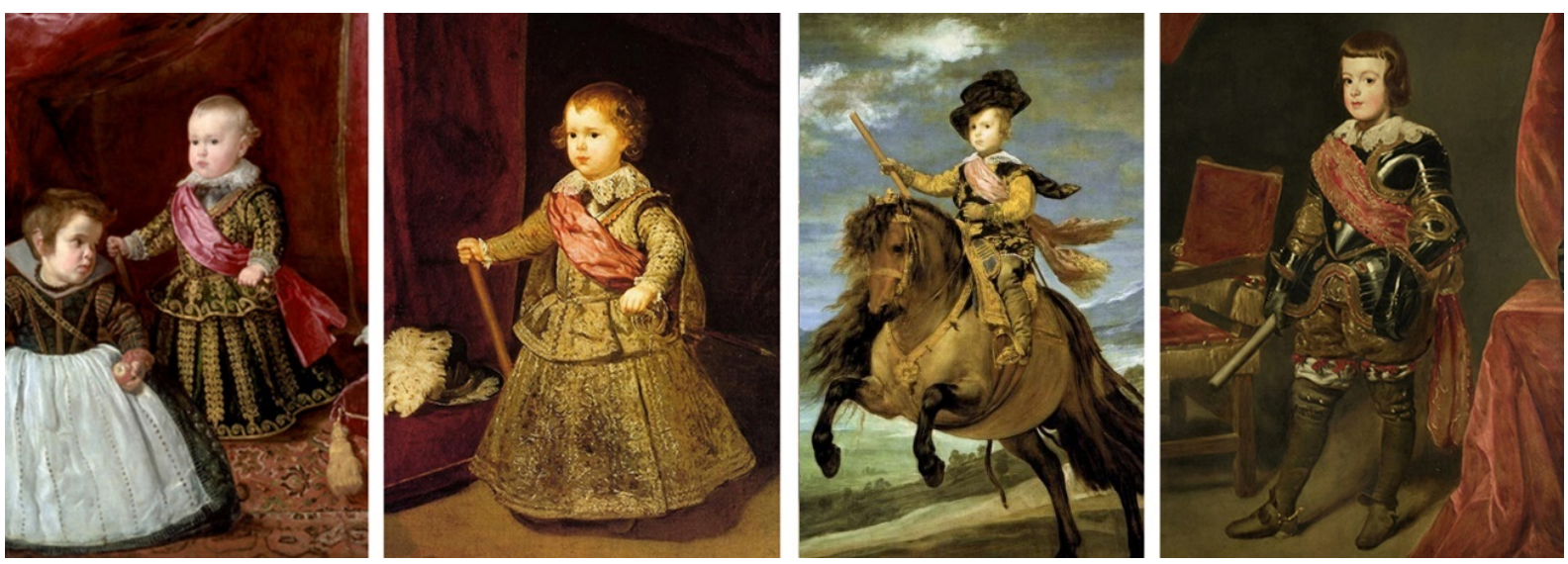

Fonte: Disponível em https://www.museodelprado.es. Acesso em 6 mar. 2019.

Em especial, chamamos atenção para a terceira e quarta imagem, pois apresentam Baltasar desempenhando feitos valorizados entre os homens, como montar a cavalo e se preparar para a guerra, respectivamente. Diante dessas pinturas, parece-nos que, mesmo com a pouca idade, Baltasar não expressa nenhum medo ou dificuldade para montar a cavalo, para se vestir com armaduras pesadas e pouco flexíveis ou para manusear armas - como registrado em outra pintura de Velázquez, intitulada O Príncipe Baltasar Carlos, caçador (1635-6). Além desses valores viris que atravessam as representações de Baltasar, um outro elemento, uma fita rosa, marca seu corpo e pode ser tomada como exemplo de que, nesse período, crianças maiores e pertencentes à família real eram identificadas conforme seu gênero, sendo o rosa um marcador de masculinidades.

O azul, por sua vez, fora utilizado para identificar o gênero feminino pela delicadeza e leveza conferidas à cor e a suas associações com a iconografia cristã. Sobre isso, Michel Pastoureau e Dominique Simonnet (2006) afirmam que o azul - cor que tem sido uma das preferidas entre os/as ocidentais desde 1890 - nem sempre fora percebido ou bem quisto. Explicam, por exemplo, que na Roma Antiga, o azul fora considerado a cor dos povos bárbaros e estrangeiros. Além disso, naquele contexto, ter os olhos azuis representava mau sinal, tanto para homens como mulheres. A ausência do azul em textos antigos, inclusive, levou filósofos do século XIX a supor que algumas civilizações não foram capazes de perceber essa cor. Os autores argumentam que a valorização do azul só fora alcançada no século XII por causa das transformações internas na Igreja Católica. No século XII, o deus dos/as cristãos/ãs se converteu em um ser de luz; e a luz, no campo simbólico das pinturas, mosaicos, gravuras e tecelagens, por exemplo, passou a ser representada pela cor azul. Assim, nessa época, pela primeira vez no ocidente, as Artes Visuais, passaram a representar os céus com tons azulados. Até então, como explicam Pastoureau e Simonnet (2006), os céus eram coloridos de dourado, branco, vermelho ou preto. Os autores ainda chamam atenção para outra mudança proporcionada pelo catolicismo: a significativa expansão do culto a Maria. Considerando a crença de que a Virgem vive no céu, a cor azul passou, então, a ser empregada na coloração dos mantos e vestidos que cobriam o corpo de Maria. Logo, como afirmam Pastoureau e Simonnet (2006, p. 22) a "[...] Virgen se convierte en la principal promotora del ąuP".

$\mathrm{Na}$ Figura 4, a nível de exemplificação do que argumentamos até aqui, reunimos detalhes de produções de Fra Angelico (1395-1445), artista italiano, cujas produções de estilo Gótico são marcadas pelos temas e significados cristãos que vigoravam no século XV. Muito semelhantes no que tange aos aspectos compositivos, às estratégias e esquemas de representação e às posições das 
personagens, as pinturas da Figura 4 também apresentam regular emprego cromático. Destacamos que, símbolo do céu, de delicadeza, santidade e feminilidade, o azul envolve a imagem da Virgem e emoldura seu rosto nas três imagens.

Figura 4: Fra Angelico. Recortes de: Madonna de Granada, 1426; Madonna e criança, 1433; e Madonna da humildade, 1433-5
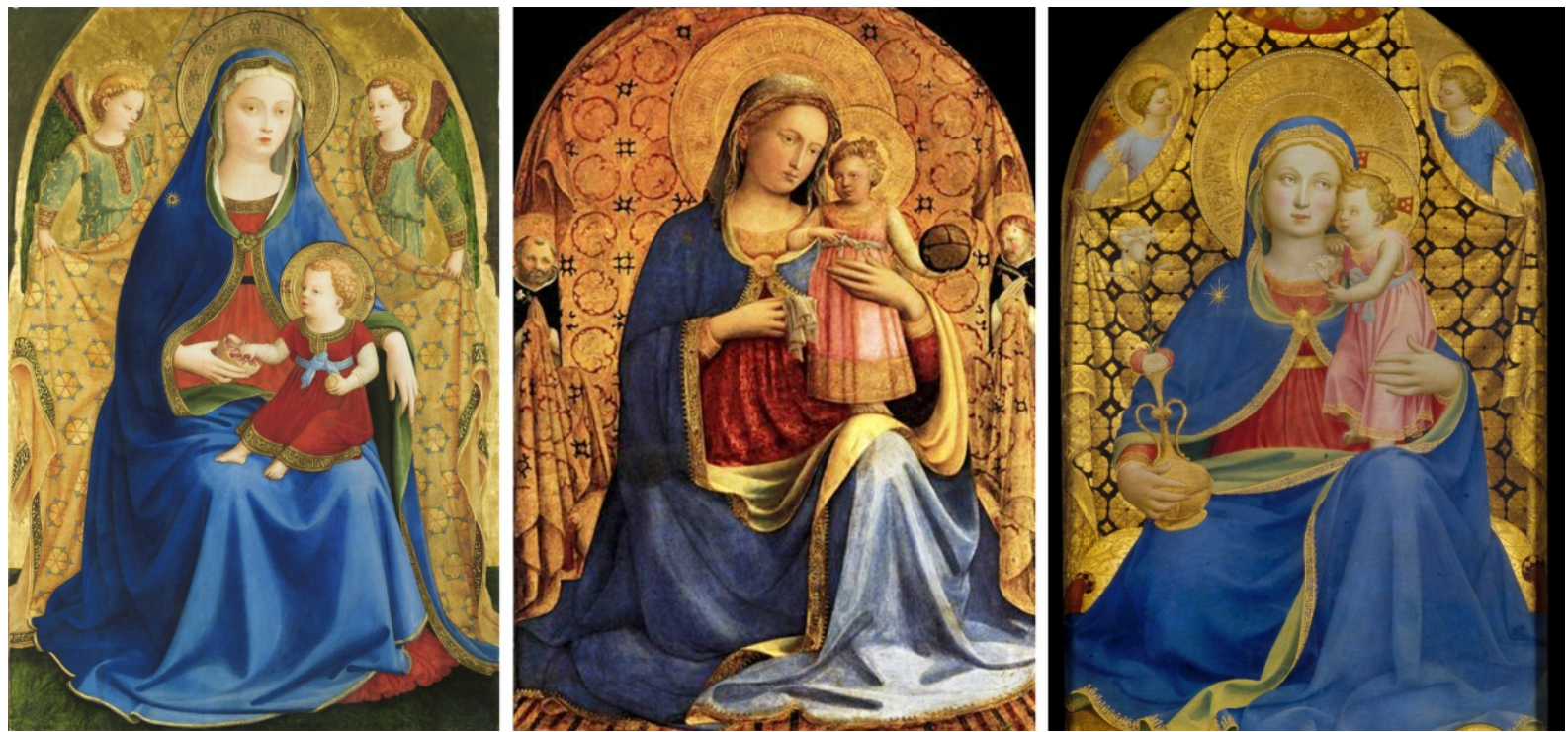

Fonte: Disponível em https://google.com.br. Acesso em 6 mar. 2019.

Nesse conjunto de pinturas se torna perceptível também o emprego do rosa e do vermelho na caracterização do corpo masculino do Menino Jesus. Encontramos convergência entre a aplicação da cor e os argumentos de Modesto Farina, Clotilde Peres e Dorinho Bastos (2006) de que, na cultura e iconografia cristãs, tons avermelhados são associados a Cristo, como metáfora ao sangue, à vida e à redenção. "É o vermelho do Salvador, o que Ele derramou na cruz para a salvação dos homens” (FARINA, PERES, BASTOS, 2006, p. 99).

O uso iconográfico que o catolicismo e a Arte Gótica estabeleceram para o rosa/vermelho e o azul nas representações de personagens, tais como Cristo e da Virgem, respectivamente, fora tomado, algumas vezes, como referência por artistas posteriores à Idade Média, como pode ser percebido nas expressões artísticas do século XVII e XVIII. Por exemplo, nas produções neoclássicas da artista suíça Angelica Kauffmann (1741-1807) como evidenciamos na Figura 5. Embora os esquemas de representação e as temáticas apresentadas sejam consideravelmente diferentes daqueles que caracterizavam a Arte Gótica, o uso generificado das cores parece guardar relações com as pinturas de Fra Angelico e com a iconografia cristã. 
Figura 5: Angelica Kauffman. Venus induz Helen a se apaixonar por Paris, 1790; Egeria entregando seu escudo numa Pompilius, 1794; e Calipso apelando ao céu e à terra para testemunhar sua sincera afeição por Ulisses (s. d.)
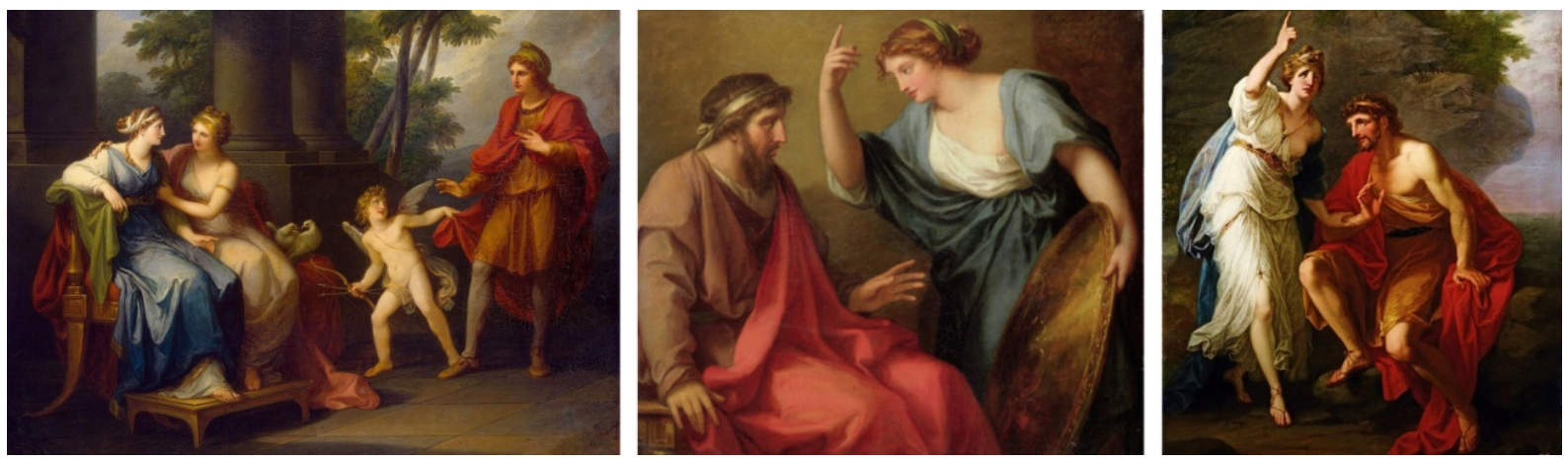

Fonte: Disponível em https://google.com.br. Acesso em 10 mar. 2019.

Quando aproximadas às pinturas de Fra Angelico, as três produções de Kauffman nos revelam que os temas mitológicos e o uso da perspectiva e a associação entre belo e a nudez corporal do Neoclassicismo que não aparecem e que, inclusive, foram negadas, pela Arte Gótica sob uma abordagem cristã. Mesmo assim, como evidenciado nas três pinturas em questão, o rosa e o vermelho foram aplicados na caracterização das vestes dos personagens homens, e o azul, nas das mulheres. Sobre isso Pastoureau e Simonnet (2006, p. 41) explicam que:

En la Edad Media el azul era más bien femenino (por da Virgen) y el rojo, masculino (signo de poder y de la guerra); ahora, en cambio, las cosas se invierten y el azul se convierte en masculino (por ser más discreto), y el rojo, en femenino. Conservamos algún rastro de ello: azul se el bebé es niño y rosa para las niñas.

Como temos demonstrado até aqui, antes do século XX, no ocidente, o azul e o rosa, por vezes, foram associados à representação de mulheres e homens, respectivamente. Por que, então, na sociedade contemporânea, o uso pedagógico da cor é exatamente inverso a isso?

\section{Depois do século XX: o fortalecimento do azul-menino e rosa-menina}

Como exemplificamos neste tópico, as mudanças de significados atribuídos ao rosa e azul tem como marca o século XX e podem ser justificadas, dentre tantos motivos, pela influência de ícones populares, pela expansão do consumismo, por estratégias publicitárias e por disputas entre movimentos sociais e grupos religiosos com conviçcões e defesas conflitantes entre si. Juntos, esses e outros fatores culturais contribuíram para que tais cores fossem, paulatinamente, vinculadas aos corpos, produtos e identidades femininas e masculinas, e para que exercessem pedagogias de gênero e sexualidade diferentes daquelas estabelecidas pela iconografia cristã. Contudo, há de se destacar que esse processo de generificação do azul e do rosa não se deu simultaneamente e que, considerando o emprego cromático, as masculinidades dos meninos e as feminilidades das meninas foram sendo caracterizadas em ritmos diferentes.

No que diz respeito às roupas, por exemplo, Jo B. Paoletti (2012) assinala que, nos Estados Unidos, o processo de generificação das vestimentas dos meninos aconteceu primeiro justamente para diferenciá-los das meninas. Se antes do século XX era habitual que as roupas das crianças fossem neutras no que diz respeito ao gênero, a partir de 1900, gradualmente, as roupas dos meninos começaram a ganhar elementos "masculinizantes", o que reflete o medo e a 
desqualificação da homossexualidade masculina - daí a necessidade de, desde os primeiros anos, rejeitar qualquer traço socialmente lido como "feminino" que um menino venha a expressar. Todavia, como explica a autora, nesse caso, a generificação das roupas dos meninos se deu pela apropriação de elementos e peças das roupas dos homens adultos, como a calça, e não propriamente pela cor azul. Em suas palavras, embora essas duas cores sejam frequentemente usadas para caracterizar os gêneros "[...] o azul nunca foi tão poderoso simbolicamente quanto o rosa. Meninas podem usar qualquer tom de azul, desde que ele seja suficientemente modificado com flores, babados e outros toques femininos. Mas o uso de roupas rosas por meninos tem sido cada vez mais raro desde 1940" (PAOLET'TI, 2012, p. 85-86, tradução nossa) ${ }^{3}$.

Paoletti (2012) ainda destaca que a história moderna do rosa como uma "cor de menina" (processo ao qual a autora se refere como pinkification) pode ser sistematizada em quatro estágios no que diz respeito às práticas culturais estadunidenses. O primeiro estágio (1900-1950) corresponde à transição de "roupas não generificadas" para "roupas generificadas". Nele, os elementos até então considerados infantis - como os vestidos, decotes e a própria cor rosa -, de modo sutil e lento, passaram a ser lidos como "femininos". No segundo estágio (1960-1980), os tons pastel e o rosa em específico caíram em desuso. A isso a autora relaciona: a) os estudos sobre o desenvolvimento infantil (que afirmavam que as cores saturadas e contrastantes eram mais adequadas para a caracterização de roupas, brinquedos e espaços infantis); e b) aos movimentos feministas (que problematizavam os estereótipos a partir dos quais as mulheres eram caracterizadas como inferiores aos homens). No terceiro estágio (1980-2000) o rosa foi conectado à feminilidade tradicional e, como reação de grupos mais conservadores às propostas dos movimentos feministas, atingiu o nível imperativo moral para crianças entre três e sete anos de idade. O quarto e último estágio, por fim, corresponde ao século XXI quando, conforme a autora, aparecem maiores resistências e problematizações quanto ao uso dicotômico, generificado e restrito dessa cor.

Apesar de a sistematização estabelecida por Paoletti (2012) ser importante para que entendamos que os significados atribuídos às cores e aos gêneros são ao mesmo tempo consequências e causas de disputas socioculturais, sublinhamos que essas disputas não necessariamente podem ser datadas ou localizadas com precisão. Em outras palavras, o que pretendemos destacar é que, inclusive na contemporaneidade, as ações e reações a respeito dos usos generificados do azul e do rosa ocorrem concomitantemente. Portanto, mesmo entre 19601980, por exemplo - período correspondente ao estágio em que a autora identificou certo desuso da cor rosa - havia personalidades, instituições e investimentos culturais que prestavam manutenção à associação dessa cor com o feminino.

Mamie Eisenhower (1896-1979), por exemplo, foi um dos ícones femininos estadunidenses que, na década de 1950, contribuiu para que a cor rosa fosse ressignificada pelo imaginário popular coletivo. Nesse sentido, tanto no que diz respeito ao tempo quanto às convicções ideológicas atribuídas ao rosa, parece-nos que Mamie expressa uma reação daquilo a que Paoletti (2012) caracterizou como sendo o primeiro estágio da história moderna da cor rosa nos EUA. Conforme explica Grayson Perry (2018), Mamie, esposa de Dwight D. Eisenhower (1890-1969), o 34 presidente dos EUA, fazia uso constante de acessórios e vestidos rosas e, nesse sentido, colaborou para que sua elegância e sensibilidade, assim como o papel de "esposa tradicional" que exercera, fossem relacionados à cor. Sua predileção pelo rosa foi recorrente também nos quartos, banheiros,

\footnotetext{
3 “[...] blue has never been as powerfull symbolically as pink. Girls can wear any shade of blue, as long as it is sufficiently modified with flowers, rufles, and other feminine touches. But pink clothing for boys has grown increasingly rare since the 1940s".
} 
cozinha e outros cômodos da Casa Branca que foram pintados e decorados com objetos rosados, durante os anos em que Mamie fora a primeira dama dos EUA.

Sobre isso, Perry (2018) reitera que Mamie se encantava pelo rosa e que enquanto acompanhava seu marido durante a carreira militar dele, levava amostras de tintas, em seus tons favoritos para pintar rapidamente suas novas dependências de forma que se sentisse em casa. $\mathrm{Na}$ Figura 6, reunimos uma pintura de Mamie utilizando um vestido e luvas rosas, na posse do marido em 1953, e registros fotográficos do interior de um banheiro e quarto decorados a pedido dela.

Figura 6: Retrato de Mamie com seu icônico vestido rosa, 1953; e imagem de banheiro e quarto decorados por ela
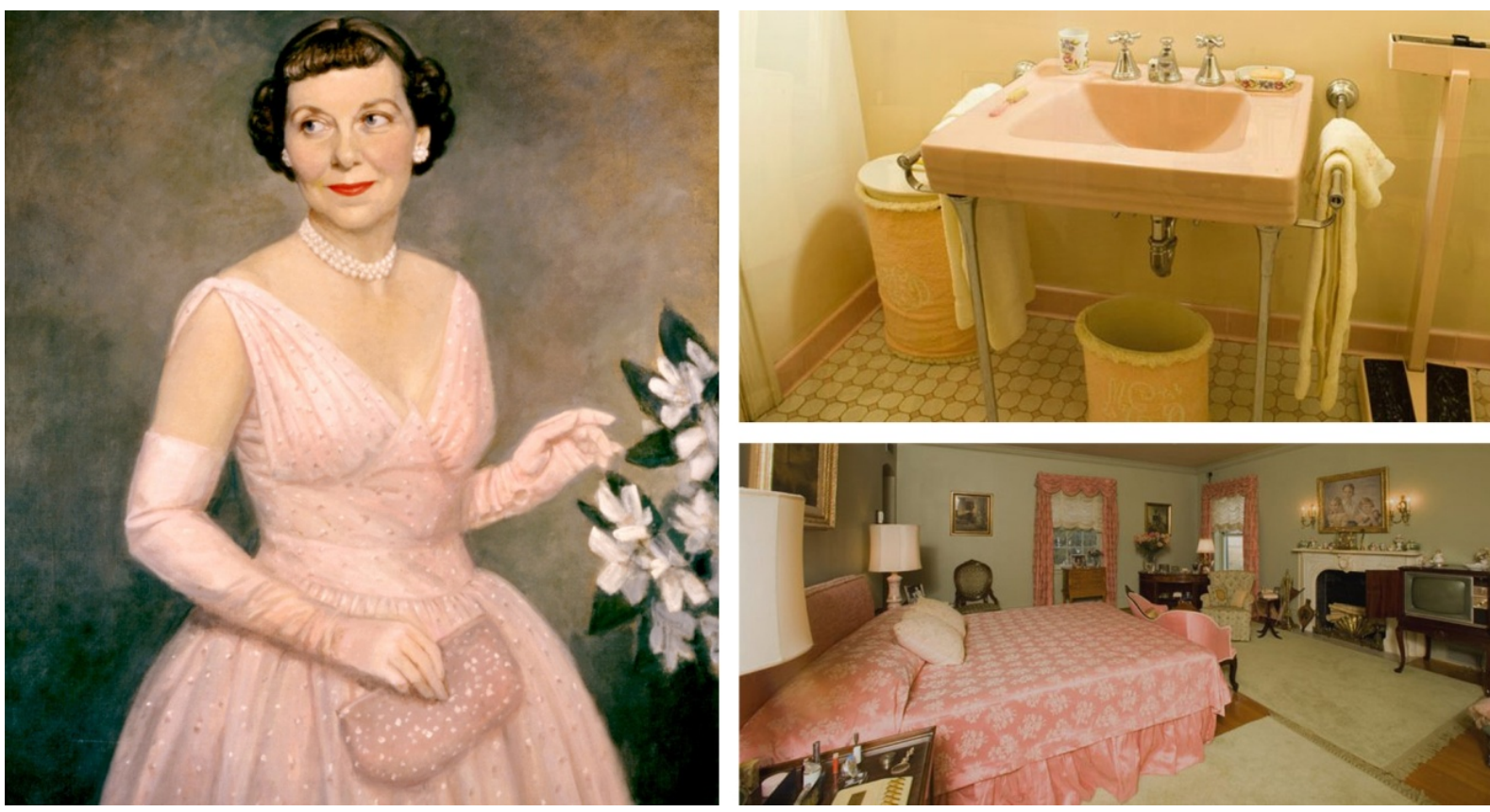

Fonte: Disponível em https://www.whitehousehistory.org/bios/mamie-eisenhower e

https://savethepinkbathrooms.com/why-mamie-eisenhower-loved-pink-more-insight-from-the-eisenhowernational-historic-site/. Acesso em 10 mar. 2019.

Nesse período, ainda sob efeito do término da II Guerra Mundial, as mulheres estadunidenses foram culturalmente incentivadas a abandonar seus postos de trabalho fora de casa e a retomar os espaços domésticos e a dependência a partir dos quais a noção de "boa esposa" fora idealizada. Foi também em meados do século XX que as imagens publicitárias passaram a fazer usos estratégicos do azul e do rosa para diferenciar os produtos infantis endereçados aos meninos e às meninas. Mesmo na década de 1950, as propagandas televisivas separavam os brinquedos por gênero, mancando-os com sons, qualidades e cores diferentes, como observa Juliet Schor (2009, p. 34). Já nessa época, os "[...] anúncios dirigidos aos meninos traziam locutores falando em voz alta, colisões de veículos e algumas animações. As garotas recebiam comerciais mais animados, suaves e "cor-de-rosa". Barbie, a boneca criada por Ruth Handler (1916-2002) em 1959, pode ser considerada protagonista nessa espécie de projeto para associar a cor rosa aos corpos, comportamentos e valores femininos. Em uma época em que todas as bonecas imitavam corpos de bebês, a idealização de uma boneca adolescente, cujas curvas e volumes possibilitavam o uso de roupas semelhantes às dos catálogos de moda, fora recebida com entusiasmo pelas meninas. $\mathrm{O}$ conceito intrínseco a Barbie ampliou os significados do "brincar com boneca" para além da ideia 
de cuidados e maternidade, contemplando também "trocar de roupas", "maquiar-se" e "fazer compras com as amigas". Assim, é possível supor, que as roupas, bolsas, sapatos, maquiagens, óculos, móveis, casas e demais acessórios rosas que alternadamente acompanharam a boneca desde a sua criação (Figura 7) asseveraram as relações entre a cor rosa e as identidades femininas, associando-as à vaidade e consumo.

Figura 7: Boneca Barbie e seus acessórios

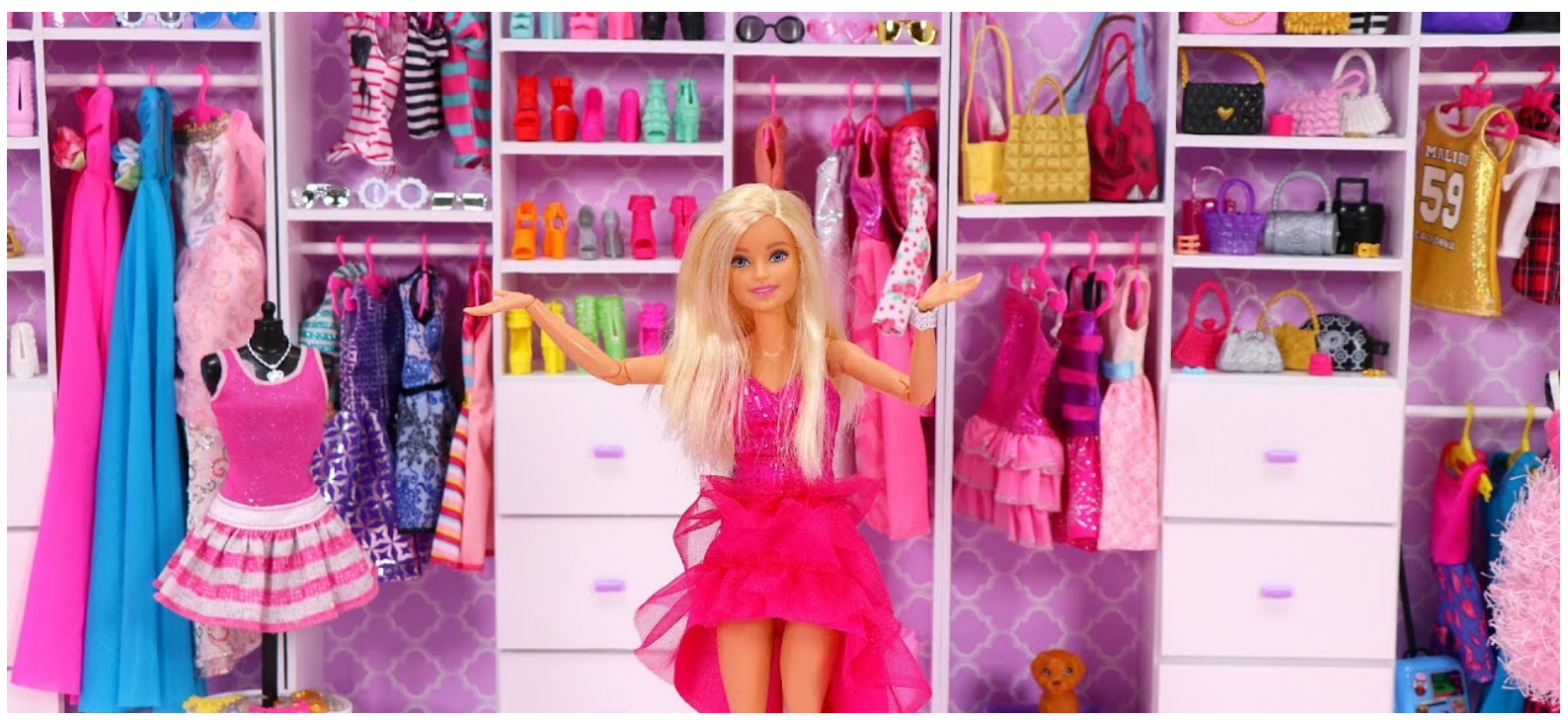

Fonte: Disponível em https://www.metropoles.com/vida-e-estilo/comportamento/barbie-ostentacao-relembreos-acessorios-mais-luxuosos-da-boneca. Acesso em 10 mar. 2019.

Como destacamos anteriormente a partir daquilo que Paoletti (2012) chamou de terceiro estágio da história moderna da cor rosa, a abordagem histórica e artística do uso generificado dessa cor também pode ser aproximada das reações aos movimentos feministas do século XX. Entre os anos 1980 e 2000, o rosa foi arbitrariamente empregado na caracterização das meninas cujos/as familiares se mostravam contrários/as às proposições dos movimentos feministas que visavam questionar os estereótipos de gêneros e os papéis tradicionais que as mulheres eram cobradas a desempenhar. Nesse ponto, Paoletti (2012) e Passarelli (2018) concordam que, como um imperativo, a adoção do rosa para caracterizar as meninas soou como uma reafirmação dos valores defendidos por grupos mais conservadores.

É preciso destacar que, nesse mesmo período, o desenvolvimento e a popularização da ultrassonografia e dos exames de gravidez também oportunizaram que o azul e o rosa fossem adotados, massivamente, para identificar os/as bebês. Essa tecnologia possibilitou que os/as familiares se preparassem não mais para a vinda uma criança qualquer, mas de uma cujo gênero já fora antecipado pela identificação de seu sexo. Conforme explica Ferreira (2018, p. 13), ter conhecimento prévio sobre o sexo da criança impulsionou novas "[...] práticas culturais como, por exemplo, o chá de bebê, onde se presenteia a mãe com utilidades para a criança e, também, acelerou a instauração definitiva da lógica do rosa para meninas e o azul para meninos". De modo semelhante, Ivana Guilherme Símili e Renata Franqui (2015) chamam atenção para as roupas infantis e para o advento da produção em massa no século XX que, numa lógica capitalista, criaram expectativas e inscrições para o gênero do/o bebê antes mesmo de seu nascimento. Segundo as autoras, para a elaboração dos enxovais, por exemplo, os/as familiares, ainda hoje, costumam se 
basear na seguinte suposição: “[...] se a criança for menino, será entendido que ele gostará de carrinhos, de bolas e que a cor preferida será o azul; se for menina, que gostará de bonecas [...], e que a cor preferida será o rosa!" (SÍMILI, FRANQUI, 2015, p. 279).

Nos EUA, conforme Paoletti (2012), uma, dentre tantas campanhas publicitárias, contribuiu significativamente para que, mesmo antes do nascimento da criança, seus/as familiares escolhessem o rosa e o azul como marcadores de seu gênero, como destacamos na Figura 8.

Figura 8: Fraldas Luvs
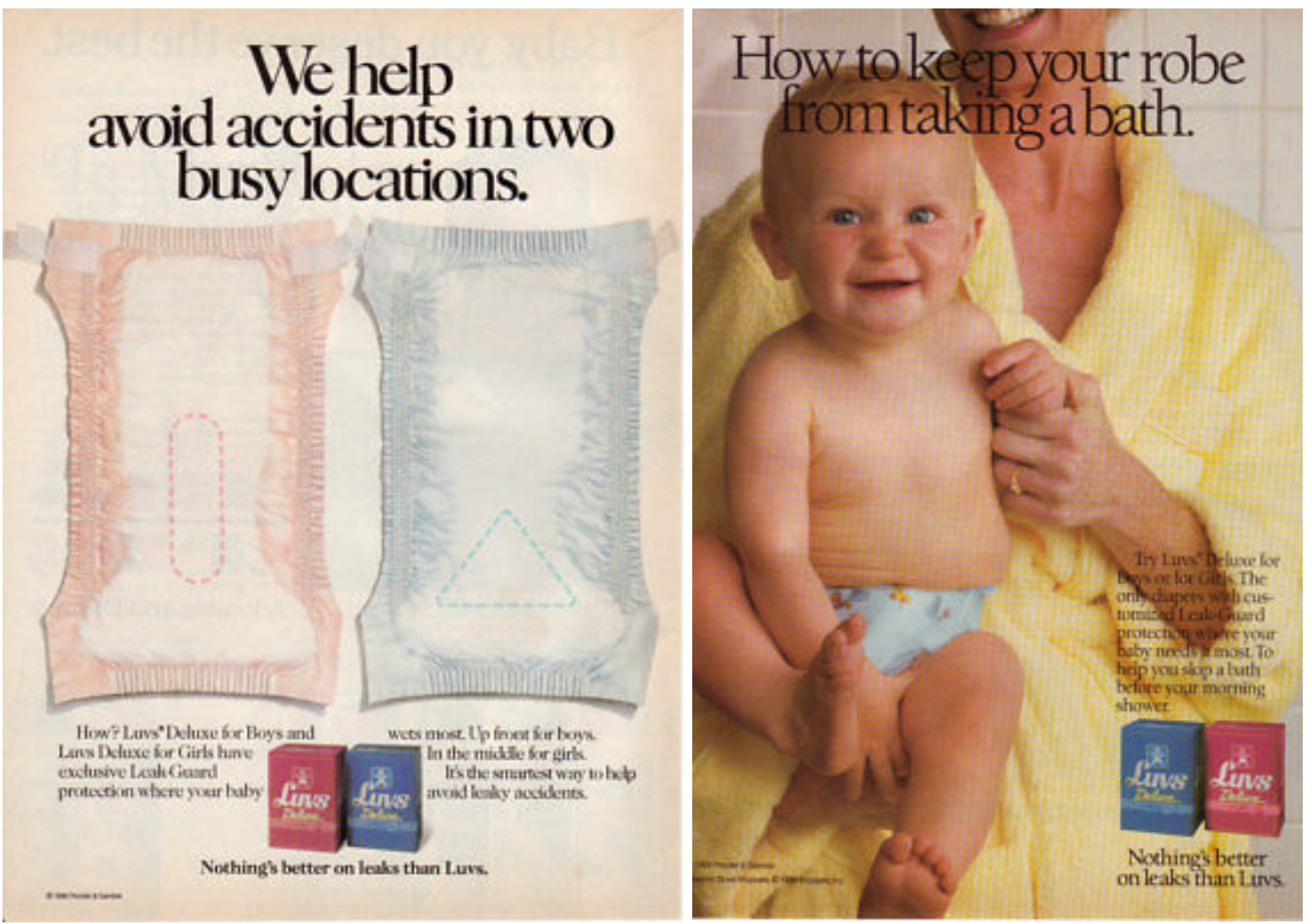

Fonte: Disponível em https://br.pinterest.com/pin/817614507324422215/. Acesso em 10 mar. 2019.

Em 1985, a marca Luvs foi a primeira a inserir no mercado de consumo fraldas descartáveis em versões específicas "para meninos" e "para meninas". Com isso, argumentavam, que a marca inovava no que diz respeito às diferenças da localização do estofamento que proporcionava a absorção da urina (na frente, para eles, e em baixo, para elas). Ocorre que, para além dessa diferença funcional, como pode ser percebido na Figura 8, a marca Luvs promoveu outras diferenças entre as fraldas de meninos e meninas, desta vez, no campo simbólico: o emprego generificado do azul e rosa.

Nesse ponto, destacamos que a identificação dos órgãos sexuais em si, seguida da afirmação "é um menino" ou "é uma menina" não apenas caracteriza o corpo infantil como masculino ou feminino, respectivamente, mas o produz como tal. Além disso, impulsiona outras afirmações regulatórias e controladoras de corpos, tais como "meninas são mais calmas", "mulheres não dirigem bem", "meninos não choram", "fale como homem" e, finalmente, "menino veste azul e menina veste rosa". Essas expressões podem ser aproximadas daquilo a que Paul B. Preciado (2017) 
se refere como enunciados performáticos. Para o autor, esses “[...] performativos do gênero são fragmentos de linguagem carregados historicamente do poder de investir um corpo como masculino ou feminino, bem como de sancionar os corpos que ameaçam a coerência do sistema sexo/gênero [...]" (PRECIADO, 2017, p. 28-29).

Esses e outras expressões culturais que atuaram como pedagogias de gênero e sexualidade no século XX repercutem na contemporaneidade, sobretudo, nas maneiras como meninos e meninas interagem com as cores e formulam seus gostos cromáticos na Educação Básica. Márcia Gobbi (2015), por exemplo, localiza reflexos dos enunciados performáticos em desenhos feitos por crianças da Educação Infantil e na predileção cromática que elas manifestam. Do montante de quase 90 desenhos infantis coletados, a autora observa que mais da metade se utilizava da cor rosa; e que, em todos os casos, o rosa estruturava linhas e formas de personagens femininos. Supõe, assim, que o rosa não é abordado pelas crianças como uma cor qualquer - por meio da qual poderiam desenhar flores, prédios, árvores, homens e mulheres - mas como um marcador de feminilidades. Na Figura 9 apresentamos dois desenhos coletados e analisados pela autora.

\section{Figura 9: Desenhos de crianças da Educação Infantil}

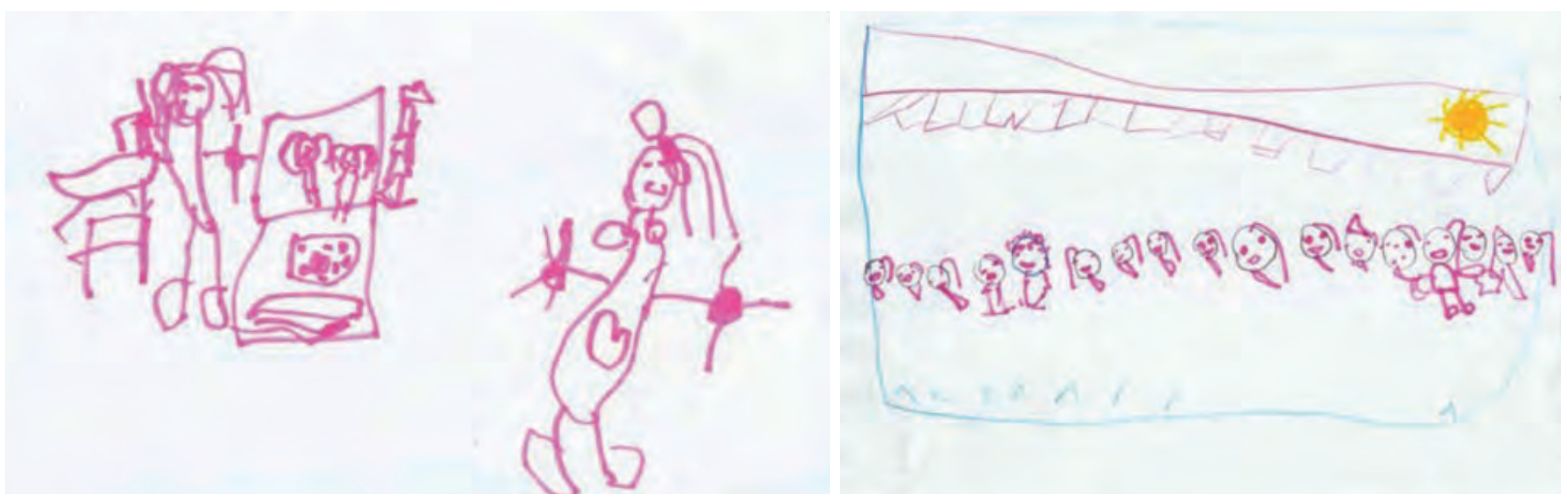

Fonte: Gobbi (2015, p. 150 e 154, respectivamente).

No primeiro desenho, uma aluna retrata sua mãe e irmã trabalhando juntas nos afazeres domésticos. No canto esquerdo, a mãe, com muitos braços, parece desempenhar muitas tarefas ao mesmo tempo. No segundo desenho, outra aluna representa a família interagindo na construção de uma casa. Nesse caso, especificamente, não é apenas o rosa que caracteriza as personagens quanto ao seu gênero, mas também o azul. Enquanto as linhas que dão forma aos rostos das mulheres são rosas, as que dão formas aos homens são azuis. Diante do emprego do rosa que as crianças, duas meninas, fizeram em seus desenhos para marcar figuras femininas, Gobbi (2015, p. 150) localiza uma espécie de "[...] imposição do rosa [...] que, perversa e vagarosamente, vai ensinando e constituindo qual é o lugar das meninas e das mulheres e do feminino". Ainda que se tratem de normativas de gênero, essas associações cromáticas podem ser problematizadas e transgredidas por profissionais da educação e também por sujeitos infantis. Como exemplifica Gobbi (2015, p. 149) ao relatar o seguinte caso: quando um menino participante da pesquisa faz uso do lápis rosa e outro lhe questiona "não é cor de menina?", ele prontamente responde "nada a ver" e permanece se utilizando da cor.

A pesquisa realizada por Luciana Borre Nunes (2010), por sua vez, evidencia o medo e o desprezo que meninos, estudantes do Ensino Fundamental manifestam por materiais escolares rosas ou caracterizados por outros marcadores de feminilidade. Quando questionado sobre a diferença entre os cadernos de menino e de menina, um garoto responde: "A gente não é bicha 
[...]. É o fim da picada: meninos com coisa de menina é estranho, esquisito. As meninas usam aqueles cadernos porque os personagens são meninas e fazem coisas de meninas... Coisas rosas." (NUNES, 2010, p. 88). A essa discussão, Susana Rangel Vieira da Cunha (2010) apresenta dados semelhantes. Em uma pesquisa realizada com crianças de até 6 anos, a autora pediu que elas separassem um conjunto de artefatos entre o que era considerado "de menino", "de menina", e o que poderia ser dos dois. Relata que "[...] durante esta atividade, surgiu a palavra gay. Uma menina disse que se um menino usasse a mochila rosa, da Barbie, ele seria diferente, um gay" (CUNHA, 2010, p. 18).

A associação que se estabeleceu no século XX entre a cor azul e a masculinidade, semelhante à associação entre a cor rosa e a feminilidade também fora intensificada pelas estratégias publicitárias, pelo apelo ao consumismo e pelo desenvolvimento da ultrassonografia. Nesse caso, porém, identificamos que o uso generificado da cor expressou-se ainda no final do século XIX, na popularização do jeans. Antes de tornar-se uma peça básica nos guarda-roupas masculinos e femininos contemporâneos e de marcar as identidades jovens e rebeldes dos anos 1950, o jeans azul foi, como relata Passarelli (2018), um símbolo da masculinidade laboral. Os primeiros sujeitos a utilizar esse modelo de calça, conforme a autora, foram homens trabalhadores: marinheiros genoveses - apelidados de genes pelos/as franceses/as, e de jeans pelos/as estadunidenses. O jeans azul se tornou popular no final do século XIX, pela necessidade de uso de um tecido forte, porém, maleável o bastante para resistir aos movimentos e atritos implicados no trabalho pesado. O jeans, então, como observa a autora "[...] se tornou item do vestuário de trabalho, demarcador social de classe definido primeiramente como item do guarda-roupa masculino, visto que eram apenas homens que trabalhavam nesses postos" (PASSARELLI, 2018, p. 31). O uso do azul para a coloração do jeans, por sua vez, pode ser explicado por uma questão de reação química. Como explica a autora, diferente dos demais corantes, o azul índigo se liga à parte externa dos fios do jeans, assim, conforme a peça é lavada, os corantes azuis são paulatinamente removidos levando consigo fragmentos de fios - o que deixa o tecido mais maleável.

Inicialmente um item de uso exclusivo de trabalhadores homens, o jeans, em meados do século XX, tornou-se ícone junto a outro símbolo da masculinidade estadunidense: o cowboy. Douglas Pastori e Paula Visoná (2009) destacam o cinema como meio de comunicação que contribuiu para a ascensão e popularização das visualidades de far west, dentre elas a do ícone do cowboy - personagem que, como assinalam, usava jeans. Além disso, como pode ser observado na Figura 10 - em que reunimos duas fotografias da estadunidense Dorothea Lange (1895-1965) em que trabalhadores usam jeans e um anúncio da marca Levi's da década de 1950 - as imagens, como artefatos culturais, mais uma vez, contribuíram para o uso generificado das cores. 

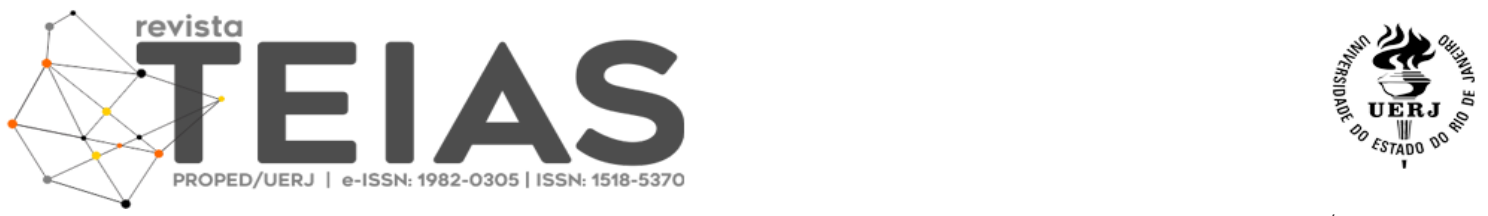

DOI: $10.12957 /$ teias. 2020.46113

Figura 10: Imagens superiores - Dorothea Lange. Seis Fazendeiros do Texas, 1937; e Grupo de Fazendeiros (1939); imagens inferiores, publicidade da marca Levi's (1950)
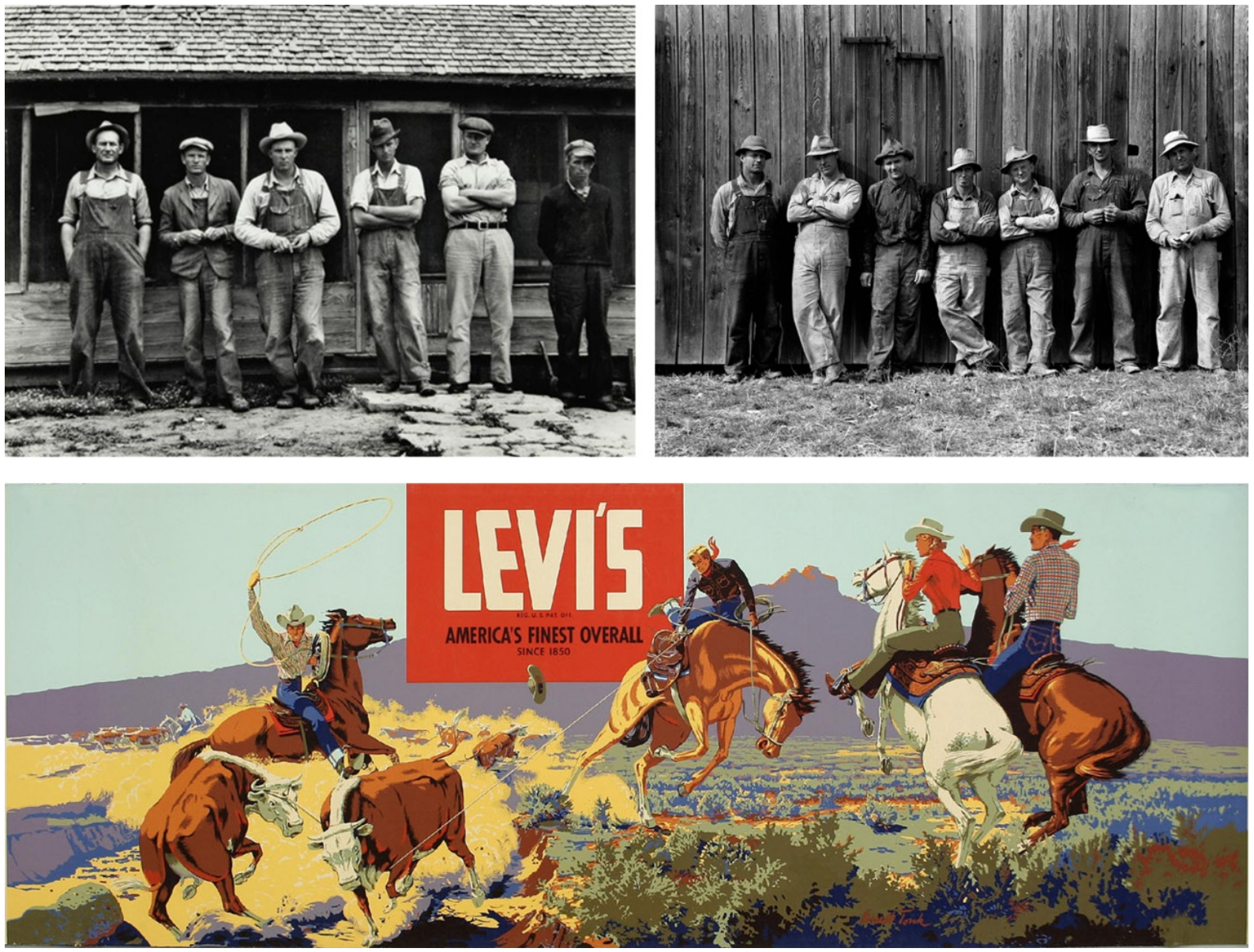

Fonte: Disponível em https://www.ssplprints.com/image/96484/lange-dorothea-displaced-tenant-farmerstexas-may-1937 e https://priya408.wordpress.com/day-7-levis-jeans-history-in-1940-1950s/. Acesso em 5 mar. 2019.

Pela praticidade e conforto proporcionados a marinheiros, mineradores, fazendeiros e cowboys do final do século XIX e início do XX, o jeans azul pode ser tomado como exemplo e como elemento reforçador da associação entre azul e masculinidade. Em análises da moda contemporânea, Símili e Franqui (2015, p. 287) destacam que ainda hoje uniformes e roupas laborais são confeccionados e/ou tingidos de azul, o que reitera, segundo elas, o "[...] papel atribuído ao ser masculino em nossa sociedade, o qual deve ser trabalhador e, ainda, o principal provedor do lar". Ainda que mais recentemente a cor rosa tenha sido reaproximada da masculinidade no campo da moda (PAOLET'TI, 2012; PASSARELLI, 2018), se considerarmos as pesquisas de Raewyn Connell (2016) e sua defesa de que o machismo oprime também os homens que não correspondem ao ideal hegemônico de masculinidade, é provável que, em uma sociedade homofóbica, um menino ou adulto que use uma camisa, mochila e acessório rosa, por exemplo, tenha seu gênero e sexualidade questionados. Os estigmas que o rosa confere à masculinidade são exemplificados por Passarelli (2018) a partir da iconografia dos campos de concentração nazista, da II Guerra Mundial. Destaca que houve um sistema de ícones a partir dos quais os sujeitos considerados inferiores, portanto marginalizados, eram identificados. Em suas palavras, esse "[...] 
sistema era indicativo de segregação e usava cores para identificar grupos. Um triângulo rosa era usado para identificar homens homossexuais" (PASSARELLI, 2018, p. 24). Esse aspecto histórico, em certa medida, ajuda a entender os motivos pelos quais ainda hoje, em alguns grupos, o uso do rosa é considerado pejorativo e inadequado entre homens.

\section{A Arte Contemporânea e as fissuras no uso convencional do azul e do rosa}

Apesar do uso convencional do rosa e azul para a manutenção de concepções tradicionais sobre feminilidade, masculinidade e infância, na Arte Contemporânea há situações em que essas mesmas cores foram e são utilizadas para problematizar as relações de gênero e para provocar fissuras nessa sistematização cromática que parece ser tão rígida. São exemplos disso, as produções artísticas da sul coreana Jeongmee Yoon (1969-), das brasileiras Bia Leite (1990-) e Panmela Castro (1981-), e mesmo aquelas de minha autoria. Em Projeto Rosa e Azul, iniciado em 2005, Jeongmee Yoon aborda questões como o consumismo, o desenvolvimento de gostos infantis específicos e as relações de gênero, como em destaque na Figura 11.

Figura 11: Jeongmee Yoon. Seunghuyk e suas coisas azuis, 2007; e Tess e suas coisas rosas, 2006
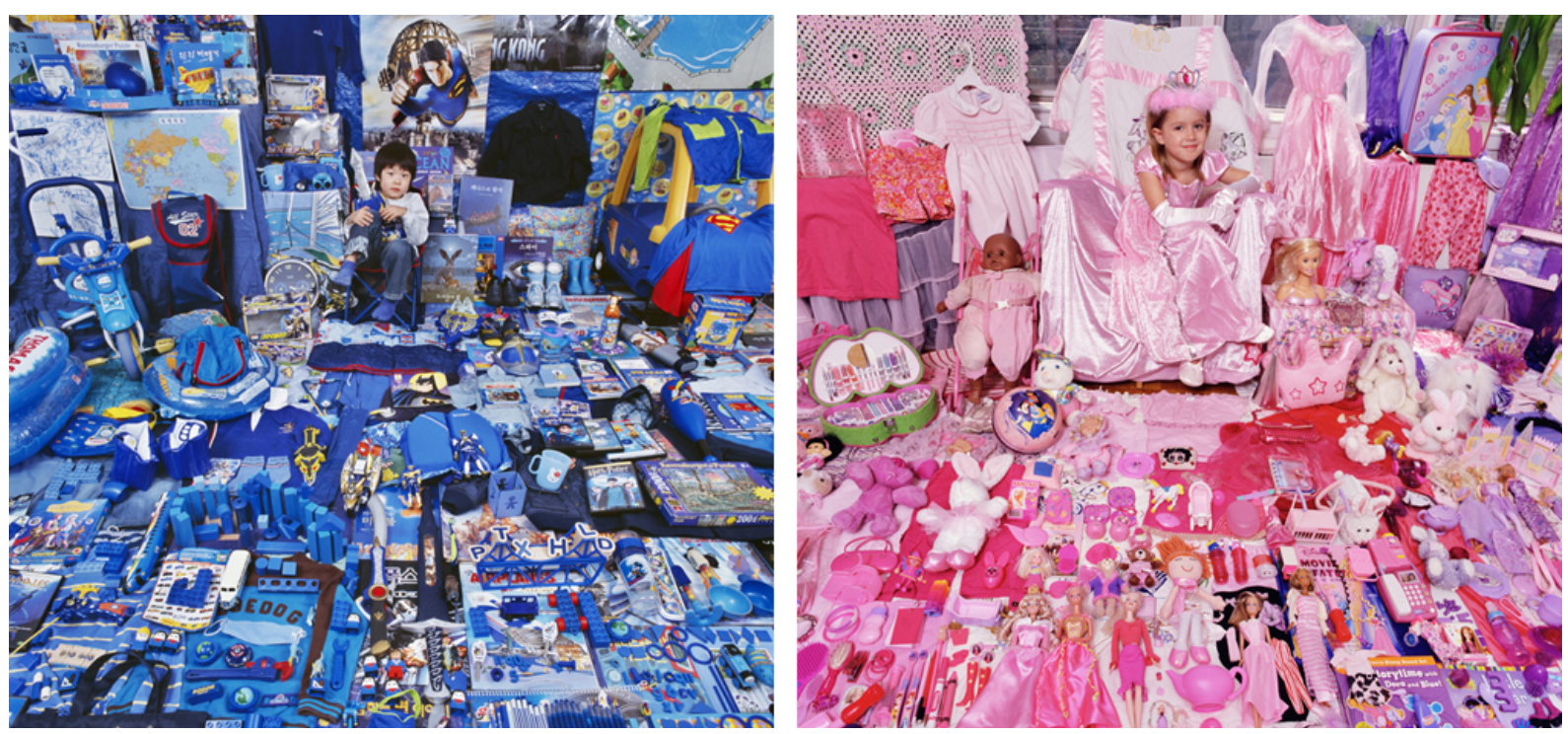

Fonte: Disponível em http://www.jeongmeeyoon.com. Acesso em 5 mar. 2019.

$\mathrm{Na}$ Figura 11 reunimos exemplos de imagens em que a artista fotografa meninos e meninas envolvidos pelos artefatos azuis e rosas com os quais convivem. No site oficial da artista, Jeongmee explica que, observando o comportamento da própria filha, percebeu a obsessão que muitas meninas manifestam por usar produtos, roupas, brinquedos e acessórios rosas. Além disso, observou que, mesmo que seu filho não tivesse demonstrado predileção pela cor azul, os/as familiares escolhiam e compravam produtos azuis para ele. A isso relacionamos o estudo de Perry (2018, p. 58) e sua análise de que os brinquedos para os meninos são projetados para criar situações de ação e combate: "Viene de color azul, preto, plateado y, por supuesto, de camuflaje. Los joguetes para ninñas giran en torno a la crianza, la belleza y lo doméstico, todo por supuesto de color rosa, y no um rosa cualquiera sino el antinatural de Barbie". O autor relata que até meados do século XX os brinquedos não eram

${ }^{4}$ Disponível em http://www.jeongmeeyoon.com. Acesso em 5 mar. 2019. 
incisivamente divididos quanto ao gênero das crianças e que, hoje, o azul e o rosa fazem uma marcação mais rigorosa daquilo que é aprovado como masculino e feminino socialmente.

Travesti de lambada e deusa das águas (2013), de Bia Leite, fez parte da exposição "QueerMusen - Cartografias da diferença na Arte Brasileira" (2017) e também ressignifica e atualiza o uso das cores azul e rosa. Nessa e em outras produções da artista brasileira (Figura 12), o rosa e o azul se inscrevem nos corpos infantis para dar visibilidades a sujeitos que não correspondem aos ideais de masculinidade e feminilidade valorizados socialmente.

Figura 12: Bia Leite. @badmonge e @mandaprohell, 2013; e Travesti de lambada e deusa das águas, 2013
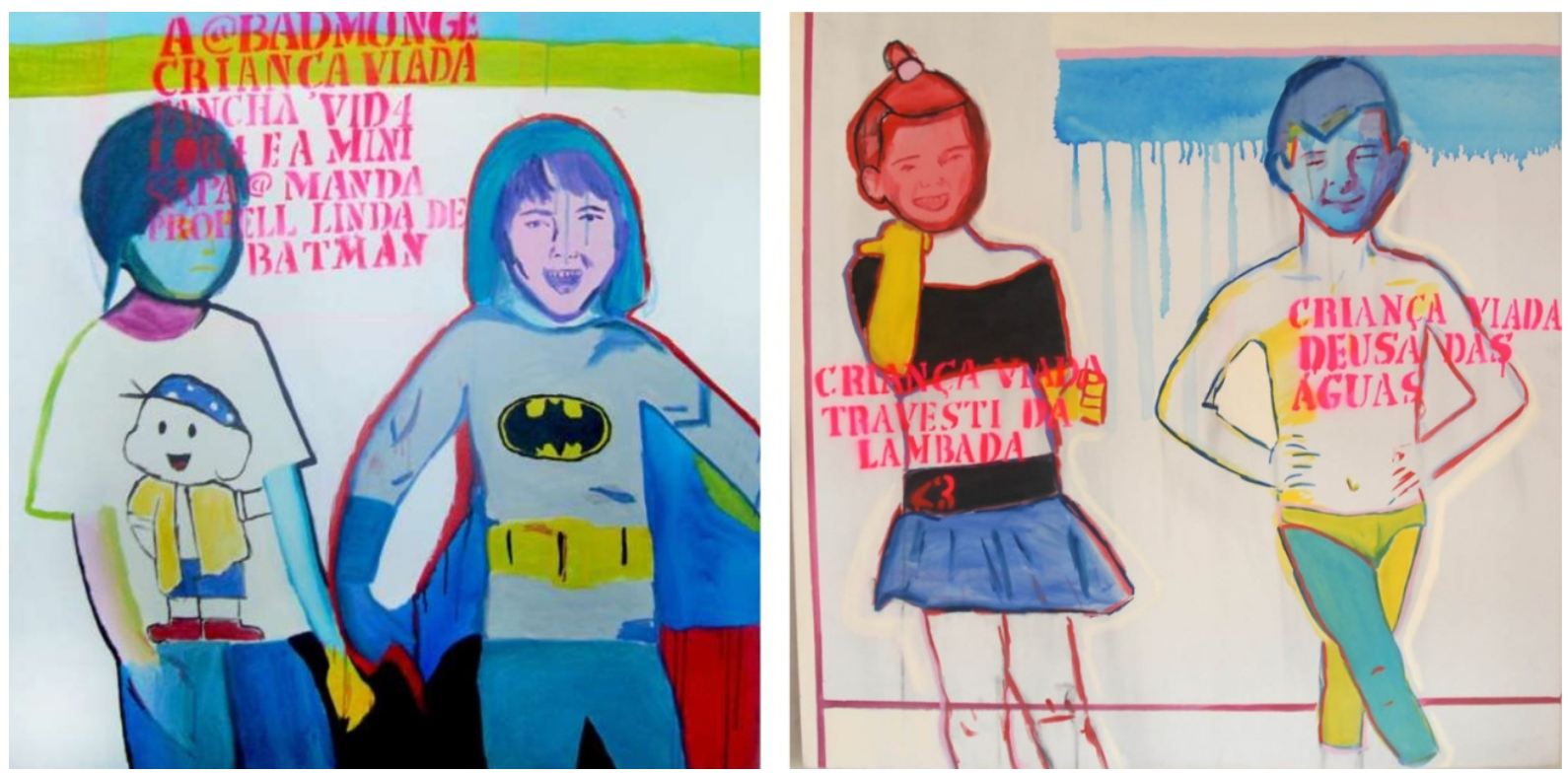

Fonte: Disponível em http://alfinetegaleria.com.br/artistas/bia-leite/. Acesso em 10 mar. 2019.

Os desenhos foram baseados em fotografias de infância, compartilhadas virtualmente entre sujeitos sob a autointitulação "criança viada" e as frases inseridas em rosa, como "criança viada deusa das águas", sugerem comportamentos transgressores e marginalizados no que diz respeito às normas convencionalmente estabelecidas para sujeitos infantis.

Panmela Castro, por sua vez, também recorre ao uso estratégico da cor rosa para dar visibilidade às pedagogias de gênero e sexualidade que interpelam as meninas desde a infância, conduzindo-as a desempenharem condutas socialmente aprovadas. O emprego do rosa nas performances, instalações, pinturas e esculturas criadas pela artista brasileira provoca reflexões e críticas quanto ao ideal de feminilidade alicerçado na delicadeza, vaidade e submissão. Em suas produções artísticas, o feminino está em diálogo com paisagens urbanas e, a partir de excessos, problematiza estereótipos que envolvem as mulheres, suas identidades e corpos. Há um excesso de tecidos, de adereços, de dobras, de camadas, e de texturas. Há um excesso de rosa. Na Figura 13, reunimos imagens seis produções da artista, todas distintas no que diz respeito aos suportes e expressões, porém, semelhantes no que diz respeito ao rosa sobressalente.

${ }^{5}$ A exposição foi cancelada sob acusação feita por grupos contrários à mostra, como o Movimento Brasil Livre (MBL) de incitar a pedofilia, a zoofilia e a intolerância religiosa. Posterior a isso, a exposição foi realizada no mesmo ano, no Rio de Janeiro. 
Figura 13: Panmela Castro. Imagens de: Rupturas, 2011; A Imitação da Rosa, 2016; Pedras, 2018; Femme Maison (vestido), 2017; Femme Maison (casa), 2017; e Cópula, 2019
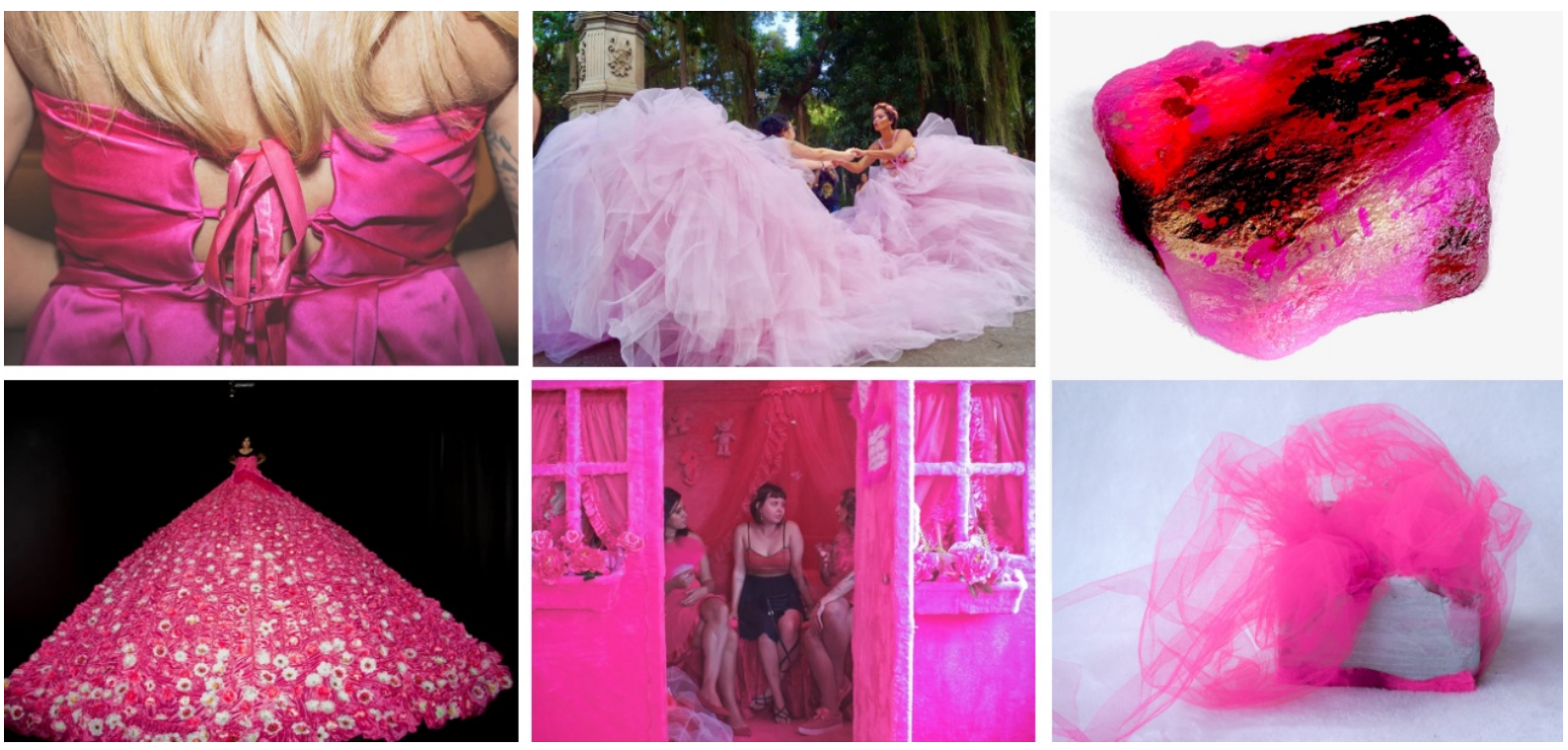

Fonte: Disponível em https://panmelacastro.carbonmade.com/. Acesso em 10 mar. 2019.

Por fim, em MonuMENtal (2020), intervenção feita por mim, João Paulo Baliscei (1989-), dez pedras foram pintadas de uma tonalidade específica de azul. Sob essa cor, as pedras não foram só fisicamente modificadas, mas também pareceram ter adquirido outros significados que não mais combinavam com seus pesos, formatos e com a agressividade e força que lhes eram até então atribuídas. O plástico bolha (com o qual as pedras foram embrulhadas individualmente) e a palavra "Frágil" (bordada em etiquetas presas às pedras) potencializaram ainda mais esse contrate. A intervenção consistiu em posicionar essas pedras em dez monumentos cívicos da cidade de Maringá, noroeste do Estado do Paraná, os quais exaltam figuras masculinas. Os bustos, painéis e estátuas "celebram" as conquistas de homens políticos, esportistas, artistas e colonizadores a partir de um viés estereotipado de masculinidade.

A inserção das pedras intentou, ainda que momentaneamente, problematizar os enunciados valorizados por aqueles monumentos. $\mathrm{Na}$ Figura 14, há um retrato meu, com nove das dez pedras e, ao lado, registro das nove ${ }^{6}$ inserções, feitas, todas elas, em monumentos que prestam homenagens a figuras masculinas. Os significados que essas e outras estátuas de homens produzem guardam relação com aquilo que, em outra pesquisa, denominamos de Projeto de Masculinização dos Meninos, projeto “[...] a partir do qual os garotos são orientados a manifestar comportamentos específicos que envolvem violência, coragem e a não expressão do medo; e a partir do qual também são corrigidos e/ou punidos caso expressem feminilidade" (BALISCEI, 2020, p. 22).

\footnotetext{
${ }^{6} \mathrm{~A} 10^{\circ}$ pedra fora posicionada não em um espaço externo, mas sim na sala da casa do próprio artista para lhe lembrar de aprender a demonstrar orgulho pela fragilidade e sensibilidade que sua masculinidade pode assumir.
} 

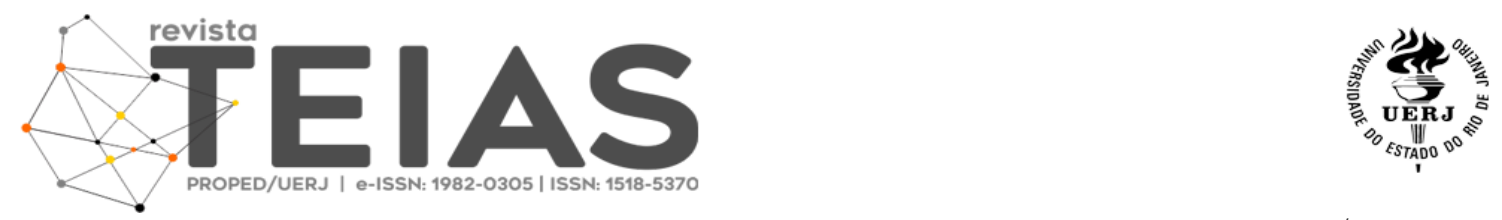

DOI: $10.12957 /$ teias. 2020.46113

Figura 14: João Paulo Baliscei. MonuMENtal, 2020

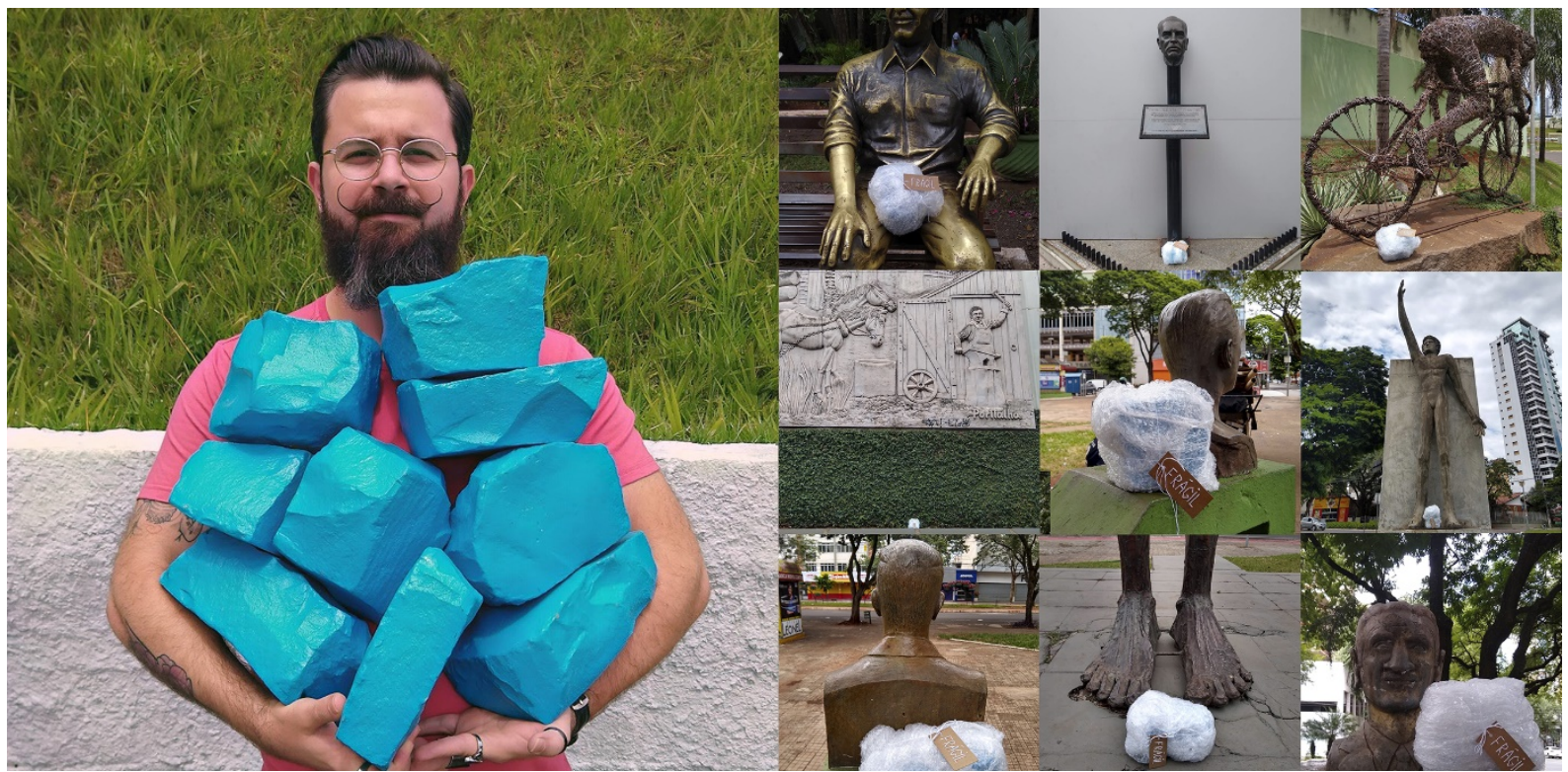

Fonte: Registro e arquivo do autor, 2020.

Consideramos, portanto, que as expressões artísticas apresentadas neste tópico estabelecem outros significados para as cores azul e rosa, fugindo, criticando, ironizando e problematizando estereótipos de gênero que recorrem a representações pouco complexas para caracterizar as masculinidades e feminilidades contemporâneas. Apesar das diferenças culturais, técnicas e formais que constituem as poéticas e dos processos criativos que envolveram essas produções, quando aproximamos umas das outras percebemos que, em comum, elas nos lembram que o uso generificado da cor é uma construção social. Logo, os significados atribuídos ao azul, ao rosa e até mesmo ao que é considerado masculino ou feminino, podem ser problematizados pelas referências artístico-visuais com as quais interagimos.

\section{CONSIDERAÇÕES FINAIS}

A associação entre cores e gêneros não é natural e tampouco espontânea, como demonstramos neste artigo em que o objetivo foi investigar, a partir de aspectos históricos e artísticos, como as cores azul e rosa têm desempenhados pedagogias de gênero e sexualidade em sociedades ocidentais. Primeiro verificamos que, de modo geral, antes do século XIX, não havia uma diferenciação cromaticamente específica para as crianças, conforme seus gêneros; e que o branco foi, em muitas culturas, a cor pela qual meninos e meninas foram identificados/as e representados/as. Ainda assim, localizamos em pinturas dos séculos XVII e XVIII o uso generificado das cores. Nesses casos, contudo, as associações cromáticas foram exatamente o avesso daquelas compartilhadas pelo e no senso comum na contemporaneidade: os meninos usavam rosa e as meninas, azul. Após isso, debruçamo-nos sobre produções artístico-visuais dos séculos XX e XXI para acompanhar as mudanças de significados e associações cromáticas que, paulatinamente, foram vinculados aos corpos masculinos e femininos.

Após essa síntese, voltamo-nos, mais uma vez, para a expressão "menino veste azul e menina veste rosa", da ministra Damares Regina Alves. Diante das críticas que recebeu e das manifestações contrárias que começaram a repercutir pelas mídias, a ministra explicou que quando fez esse 
pronunciamento, intencionou recorrer a uma metáfora contra a "ideologia de gênero". Nos últimos anos, o termo ideologia de gênero tem sido utilizado, sobretudo, em contextos e grupos fundamentalistas cristãos, para tentar garantir a hegemonia das concepções tradicionais sobre masculinidade e feminilidade, como demonstramos em outras pesquisas (TORY, BALISCEI, 2019, no prelo). O termo compreende que o gênero e o status de "normalidade" a ele conferido são expressões identitárias naturais ao sujeito e que correspondem ao sexo que fora identificado antes ou durante o nascimento. Logo, todo sujeito - criança, jovem, adulto/a e idoso/a — que manifesta comportamentos, desejos, sexualidades e gostos diferentes daqueles esperados para o seu gênero, é considerado "anormal" e, o mais importante, passível de correção.

Se a normativa "menino veste azul e menina veste rosa" tivesse sido lançada e divulgada não como uma diretriz, mas como um conselho ou como uma recomendação feita pela ministra, ainda assim, paradoxalmente, Damares estaria produzindo justamente aquilo que diz criticar: uma ideologia de gênero. Quando aproxima o rosa da feminilidade, a ministra evoca um ideal de gênero, portanto ideologia, e motiva uma série de associações entre "ser mulher" e os significados que, sobretudo a partir do século XX, têm sido atribuídos à cor rosa, como delicadeza, vaidade, doçura e domesticidade. Na oportunidade de explicar seu pronunciamento, a ministra explicou na mesma reportagem que "meninos e meninas podem se vestir com o que se 'sentirem melhor" e, com isso, mais uma vez, é contraditória, pois, anteriormente havia prescrito quais as cores que ela avaliava serem adequadas para meninos e meninas. Meninos e meninas podem, de fato, se vestir com o que se sentirem melhor? Para que essa pergunta se transforme em uma afirmativa - como propôs Damares Regina Alves — faz-se necessário problematizar as maneiras como os gêneros têm sido construídos e normatizados, não só pelas cores, mas também nos contextos escolares, pelas histórias legitimadas nos livros didáticos, pela representatividade política, pelas diferenças salariais e pelas políticas públicas que, muitas vezes, tomam como iguais sujeitos cujos corpos, experiências e medos são diferentes.

\section{REFERÊNCIAS}

BALISCEI, João Paulo. Provoque: cultura visual, masculinidades e ensino de artes visuais. Rio de Janeiro: Metanoia, 2020.

BURKE, Peter. Testemunha ocular o uso de imagens como evidências históricas. São Paulo: Editora Unesp, 2017.

CONNELL, Raewyn. Gênero em termos reais. São Paulo: nVersos, 2016.

CUNHA, Susana Rangel Vieira da. Menin@s nas tramas da cultura visual. In: BUSSOLETTI, Denise Marcos; MEIRA, Mirela (orgs.). Infâncias em passagens. Pelotas: Editora e Gráfica Universitária da UFPel, 2010, p. 55-78.

FARINA, Modesto; PEREZ, Clotilde; BASTOS, Dorinho. Psicodinâmica das cores em comunicação. 5. ed. rev. e ampl. São Paulo: Edgard Blücher, 2006.

FERREIRA, William. O gênero das coisas: uma análise sobre o discurso de gênero dos bens como cerca, ponte ou fenda para o consumo. In: Congresso Internacional Comunicação e Consumo COMUNICON, 6., 2018, São Paulo, Escola Superior de Propaganda e Marketing - ESPM. Anais... São Paulo, ESPM 2018.

GOBBI, Márcia. Lápis vermelho é de mulherzinha: vinte anos depois. In: FINCO, D.; GOBBI, M. A. (orgs.). Creche e feminismo: desafios atuais para uma educação descolonizadora. Campinas: Edições Leitura Crítica, 2015, p. 137-162. 
HOOKS, bell. Teoria feminista: da margem ao centro. São Paulo: Perspectiva, 2019.

JESUS, Jaqueline Gomes de. Orientações sobre identidade de gênero: conceitos e termos. Guia técnico sobre pessoas transexuais, travestis e demais transgêneros, para formadores de opinião. [Online] Brasília: 2012. Disponível em http://www.diversidadesexual.com.br/wpcontent/uploads/2013/04/G\%C3\%8ANERO-CONCEITOS-E-TERMOS.pdf. Acesso em 29 maio 2020 .

LOURO, Guacira Lopes. Gênero e sexualidade: pedagogias contemporâneas. Pro-Posições, Campinas, v. 19, n. 2, p. 17-23, ago. 2008.

LOURO, Guacira Lopes. Um corpo estranho: ensaios sobre sexualidade e teoria queer. Belo Horizonte: Autêntica, 2016.

MIGUEL, Raquel de Barros Pinto. A revista Capricho como um "lugar de memória" décadas de 1950 e 1960. 2009. Tese (Doutorado em Ciências Humanas) - Universidade Federal de Santa Catarina, Florianópolis.

NUNES, Luciana Borre. As imagens que invadem as salas de aula: reflexões sobre cultura visual. São Paulo: Ideias \& Letras, 2010.

OLIVEIRA, Megg Rayara Gomes de. O Diabo em forma de gente: (re)existências de gays afeminados, viados e bichas pretas na educação. 2017. Tese (Doutorado em educação) - Universidade Federal do Paraná, Curitiba.

PAOLETTI, Jo B. Pink and Blue telling the boys from the girls in America. Bloomington: Indiana University Press, 2012.

PASSARELLI, Ana Paula Martins. O gênero na propaganda de moda brasileira analisada a partir dos elementos de design do vestuário. 2018. Dissertação (Mestrado em Comunicação e Semiótica) - Pontifícia Universidade Católica, São Paulo.

PASTORI, Douglas; VISONÁ, Paula Cristina. Sexualidade e calça jeans: uma survey experimental de marketing. Global Manager, Caxias do Sul, Ano 9, n. 16, p. 69-86, 2009.

PASTOUREAU, Michel; SIMONNET, Dominique. Breve historia de los colores. Barcelona: Ediciones Paidós Ibérica, 2006.

PERRY, Grayson. La caída del hombre. Barcelona: Malpaso Ediciones, 2018.

PRECIADO, Paul B. Manifesto contrassexual. São Paulo: n-1 edições, 2017.

SCHOR, Juliet B. Nascidos para comprar: uma leitura essencial para orientarmos nossas crianças na era do consumismo. Tradução de Eloisa Helena de Souza Cabral. São Paulo: Editora Gente, 2009. SÍMILI, Ivana Guilherme; FRANQUI, Renata. As roupas e os gêneros: as estampas de brinquedos e de brincadeiras. Acta Scientiarum, Maringá, v. 37, n. 3, p. 277-287, jul./set. 2015.

TORY, Soraya Ayumi; BALISCEI, João Paulo. "Ideologia de gênero": dos documentos eclesiásticos às hashtags. In: Congresso Internacional Humanidades nas Fronteiras: Controvérsias Contemporâneas, 2, 2019, Foz do Iguaçu. [Anais]. Foz do Iguaçu: UNILA/UNIOESTE, 2019.

TORY, Soraya Ayumi. \#IdeologiaDeGênero: origens eclesiásticas e novas elaborações digitais. Revista Cadernos de Gênero e Tecnologia, Curitiba, no prelo. 

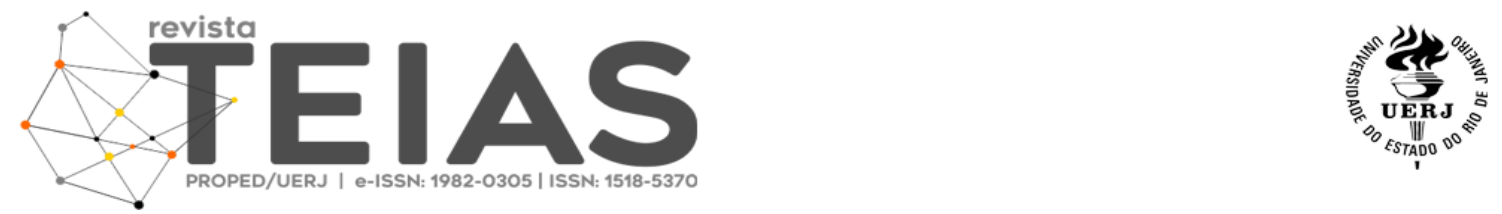

DOI: $10.12957 /$ teias.2020.46113

\section{Informações do autor}

João Paulo Baliscei

Universidade Estadual de Maringá

E-mail: jpbaliscei@uem.br

ORCID: http://orcid.org/0000-0001-8752-244X

Link Lattes: http://lattes.cnpq.br/ 6980650407208999 